\title{
SHOPPER MARKETING: A NEW PARTNERSHIP PERSPECTIVE IN MARKETING CHANNELS
}

\author{
Zoran Bogetic, Djordje Kalicanin and Dragan Stojkovic* \\ Faculty of Economics, University of Belgrade, Belgrade, The Republic of Serbia
}

\begin{abstract}
Shopper marketing has lately become a promising business initiative. The distinction between shopper marketing and traditional marketing paves the way for new relations, partnerships, and better results of retailers and suppliers. The paper explains the new perspective of marketing, with the shopper in focus. Retail has been identified as the center of gravity for enterprise cooperation and a new business consensus. The advantages and challenges of shopper marketing are also explained, including tracing the efficient category management model and partnership value creation. In the wake of the development of new category management guidelines, the paper points out the aspect of the institutionalization of cooperation in shopper marketing, as well as the future of multi-channel analysis and customer satisfaction.
\end{abstract}

Keywords: shopper marketing, shopper insights, partnership, category management

\section{JEL Classification: M21, M31, L25, L81}

\section{INTRODUCTION}

The partnership business practices of the early 1980s are gaining in importance. The strengthening of retail in marketing channels, founded on the benefits brought about by the technological revolution, has determined change in the strategic behavior of supplier organizations and their adjustment in the direction of business connection and cooperation (Petkovic \& Bogetic, 2014). This has drawn new energy positioning at points of sale and respect for the shopper and the overall shopping experience (Bogetić, Petkovic, 2014). In the early 2000s, the concept of shopper marketing

\footnotetext{
* Correspondence to: D. Stojkovic, Faculty of Economics, University of Belgrade, Kamenicka 6, 11000 Belgrade, The Republic of Serbia; e- mail: dstojkovic@ekof.bg.ac.rs
}

was innovated, and thereby a growing understanding that retail is the center of gravity in marketing emerged (O'Leary, 2013).

The flexibility of supplier organizations and adjusting to retail demands are also apparent in the relativization of the traditional focus on the consumer and cooperation in shopper marketing. The shopper the traditional preoccupation of retail - is gaining in importance and points of sale are also gaining a new direction of valuation.

The respect and capitalization of differences between the consumer and the shopper, as well as differences in the thinking and motivation of a person inside and outside the store are being affirmed (Kapferer, 2008, 145; Sorensen, 2009; Shankar, Inman, Mantala, Kelley 
\& Rizley, 2011; Pincott, 2012). The retailer and the supplier use their expertise in a harmonized manner and improve their results "very positively" (Hoyt \& Swift, 2014), which leads to an expansion of investment in shopper marketing. C. Angrisani (2015) presents the findings that expenditures on shopper marketing more than doubled in the period from 2012 to 2014, with a significant share of $13.5 \%$ in the total marketing expenditures in 2014.

Working in partnership is the essence of shopper marketing, even when the approach is narrowly observed at the level of activities for sales promotion in a store (Hoyt, 2006; Stahlberg \& Ville, 2012).

According to the influential Association of Retail Commission on Shopper marketing (Shopper Marketing Best Practices, 2010), the complementary use of expertise and the development of deep shopper insights are the key aspect of shopper marketing. It is necessary to understand the shopper's motives, attitudes and behavior, as well as alternatives of an impact on the shopper.

The retailer - supplier partnership on a comprehensive customer care is the core of the shopper marketing concept (Silveira \& Marreiros, 2014). In addition, a comprehensive view on the shopper involves a treatment in all channels and the media as well as through all available means at the level of several product categories (Shankar et al, 2011).

The customer's modern attitude towards the retail offer is increasingly more based on information (Verhoef, Neslin \& Vroomen, 2007). Many of these pieces of information are generated outside points of sale, which becomes ever more important with the development of personal mobile devices (Shankar \& Balasubramanian, 2009; Shankar, Alladi, Hofacker \& Naik, 2010). At the same time, the balance of the shopper marketing activities inside and outside the store is also very important (Wyner, 2011; Pincott, 2012) because shoppers expect promises to be fulfilled (Interbrand, 2015). Therefore, an integrated marketing approach should be the essence of shopper marketing (Fam, Merrilees, Richard, Joysa, Li \& Krisjanous, 2011).

The importance of the shopper marketing subject is multifold. On the one hand, it is a promising business strategy and tactics for achieving a better shopping experience, the development of customer loyalty and the enhancement of business results. On the other hand, it is a new approach to cooperation in marketing channels with the focus on shoppers, which carries a challenging task of bringing closer together and the harmonizing of, often quite different, perspectives on effective shopper marketing development.

The objective of this research is precisely to gain insights into the approach to harmonizing retailers' and suppliers' interests and actions in the field of shopper marketing in their mutual interest. A harmonized partnership action should ultimately be actualized through a better customer service and improved business results.

By emphasizing the businesswise importance of shoppers as the retailers and suppliers' key point of a market success, shopper marketing imposes a requirement for the additional development and redefining of product category management strategies and tactics, including new metrics for business activities and results. In this respect, apart from the above-stated objectives, the objective of the paper is to also develop a new strategic framework for product category management and the measuring of results, compliant to shopper marketing philosophy.

Having in mind the importance of the shopper marketing concept and the defined objectives of the research, this paper will test the following hypothesis:

$\mathrm{H}$ : Effective and efficient shopper marketing is based on a balanced partnership between retailers and suppliers, and this partnership is supported by improvements in category management and adjustments in performance metrics.

Customer care anytime and anywhere is the essence of the business approach to shopper marketing (Gilbride, Inman \& Stilley, 2013). Technological advancements and capabilities are the starting point for a new, comprehensive marketing model, focused on the shopper (Egol, Sarma \& Sayani, 2013). As far as the retailers' and suppliers' work in a partnership is concerned, the concept of shopper marketing focused on shoppers implies a comprehensive understanding of the research done to date and setting up new 
guidelines for sustainable positioning in marketing channels.

In this paper, we have applied a qualitative methodology and the gathering of data from secondary sources, as appropriate for the question that requires an answer (Marshall \& Rossman, 1995, 80-85; 99-107) as well as with the purpose of the holistic understanding of the shopper marketing experience (Guglielmi, 2000, 45). This choice of the methodology is also related to the fact that this field has not been sufficiently investigated into, and is also due to the developing of new knowledge and perspectives (Goldberger, 1990; Buckler \& Zien, 1997).

In the paper, the method of synthesis, the purpose of which is to synthesize the existing theoretical and practical knowledge on shopper marketing, is used, which in turn "enables the understanding of the manifested occurrence in the context of the whole" (Mesihović, 2003, 69). Having in mind that the shopper and the shopper marketing concept are the focus of attention in this paper, the humanist side of researching must also be respected, which in A. Mucchielli's $(1996,60)$ view is the characteristic of qualitative research methods. It should also be noted that, since there is no domestic evidence, this research has found its grounds in Western Economies' shopper marketing theories and practices, which is altogether the key limitation of our research.

After some clarifications in the introduction, the paper is structured into three logical unities. At the very beginning of the paper, the elements of the partnership harmonization between retailers, suppliers, and shoppers' relationships and interests at the shopper marketing platform are considered. Next, starting with the attitude that the shopper is the main preoccupation of the marketing activity, the fundamental elements of the promising business process of product category management are investigated into. The focus here is on a faster and more efficient business process. Efficient shopper marketing implies monitoring if the goals (interests) of the partners in this process are being achieved. For this purpose, it is necessary that a comprehensive performance measurement model should also be constructed. One particular section of this paper is dedicated to this challenge. In addition, the paper will point out the institutional and multichannel aspects of shopper marketing practice. Finally, the key findings of our research and the attitude on the defined research hypothesis will be presented. In addition to this, based on the current scope and the considered perspectives, the fields for future research into shopper marketing will be pointed to, including the reference to interests of domestic retailers, suppliers, and shoppers.

\section{A BALANCE OF INTERESTS AS A PRINCIPLE OF SHOPPER MARKETING}

Sustainable shopper marketing promotes the "benefitfor-all-three-parties" approach. Only in a situation when the shopper, the retailer, as well as the supplier are satisfied with the achieved results may one expect the continuity and development of the shopper marketing practice. The balance of the interest of the most important stakeholders thus becomes the key principle of the shopper marketing concept.

Matching retailers' and suppliers' needs and preferences with the best solution for the shopper is the framework of a partnership in shopper marketing. The development of a high-quality shopper insight and an understanding of long-term interests of all three parties are the starting point of cooperation. Partners develop coordinated action plans of shopper marketing at the point-of-sale level, followed by the operationalization of the agreed at the point of sale.

The possible different interests, as well as the „all three parties satisfied" perspective are illustrated in the Table 1:

Table 1 indicates possible significantly different perspectives on shopper marketing held by the retailer, the supplier and the shopper, and a possible outcome of these differences could be conflicts and problems. Thus, for example, when the supplier develops sales promotion activities by favoring its brand and without considering the effects on the planned sale of "other" offers in the retail store, the retailer is very likely to suffer real damage. It is possible, for example, that an increase in the placement of one product means a simple substitution for selling another product, 
Table 1 Different perspectives of shopper marketing

\begin{tabular}{|c|c|c|c|c|}
\hline \multicolumn{5}{|c|}{ Perspective } \\
\hline Field & Retailer & Supplier & Shopper & All three parties satisfied \\
\hline Offer view & $\begin{array}{l}\text { Profit at the category } \\
\text { level should be } \\
\text { achieved } \\
\text { Priority treatment of PL } \\
\text { (private label) brands. } \\
\text { Synergy of categories } \\
\text { portfolio, development } \\
\text { and exploitation }\end{array}$ & $\begin{array}{l}\text { Focus on their } \\
\text { own brand and } \\
\text { communication at } \\
\text { numerous points of } \\
\text { contact. } \\
\text { Timely multichannel } \\
\text { brand communication. }\end{array}$ & $\begin{array}{l}\text { Timely and accurate } \\
\text { information on the } \\
\text { wide range of offers } \\
\text { and products at all } \\
\text { points of contact. } \\
\text { A more efficient search, } \\
\text { comparison and } \\
\text { information about sales } \\
\text { promotion activities. }\end{array}$ & $\begin{array}{l}\text { Development of solutions } \\
\text { (products and/or services } \\
\text { from the manufacturer and } \\
\text { the retailer) that best suit the } \\
\text { needs and preferences of the } \\
\text { customer and communication } \\
\text { through the channels, at } \\
\text { various points of contact. }\end{array}$ \\
\hline Availability & $\begin{array}{l}\text { By managing category } \\
\text { merchandising on the } \\
\text { shelf. } \\
\text { Setting shelves } \\
\text { in a manner that } \\
\text { contributes to } \\
\text { increased visits, sales } \\
\text { and profits. } \\
\text { Multi-channel sales. }\end{array}$ & $\begin{array}{l}\text { A dominant presence } \\
\text { on the shelves, with the } \\
\text { best positions for their } \\
\text { own brands. Broad } \\
\text { coverage of channels } \\
\text { and product availability. }\end{array}$ & $\begin{array}{l}\text { The right products at } \\
\text { the right place at the } \\
\text { right time. } \\
\text { Efficient shopping. } \\
\text { Easy payment and fast } \\
\text { delivery. }\end{array}$ & $\begin{array}{l}\text { Timely availability of the } \\
\text { product in all marketing } \\
\text { channels. } \\
\text { Effective availability and } \\
\text { delivery of targeted and } \\
\text { complementary products } \\
\text { through all channels. }\end{array}$ \\
\hline Sales promotion & $\begin{array}{l}\text { Balanced combination } \\
\text { of special offers of } \\
\text { brands and products in } \\
\text { the category. } \\
\text { Profitability } \\
\text { management by } \\
\text { using sales promotion } \\
\text { solutions offered by the } \\
\text { manufacturer. }\end{array}$ & $\begin{array}{l}\text { Well thought-out } \\
\text { incentives for a better } \\
\text { quality market share of } \\
\text { their own brands. } \\
\text { Compliance of sales } \\
\text { promotion activities } \\
\text { with the strategic, } \\
\text { operational, and } \\
\text { specific objectives } \\
\text { related to the brand. }\end{array}$ & $\begin{array}{l}\text { Good deals for the } \\
\text { most desirable brands/ } \\
\text { products. } \\
\text { Appropriate or the } \\
\text { most desirable types } \\
\text { of incentives, including } \\
\text { those based on the } \\
\text { price. } \\
\text { Being well informed } \\
\text { about the pricing } \\
\text { incentives. }\end{array}$ & $\begin{array}{l}\text { Balanced timely activities of } \\
\text { sales promotion -real brands, } \\
\text { at the right place at the right } \\
\text { time. }\end{array}$ \\
\hline $\begin{array}{l}\text { Displays - } \\
\text { additional } \\
\text { positions }\end{array}$ & $\begin{array}{l}\text { Well thought-out } \\
\text { management of } \\
\text { additional positions/ } \\
\text { display during the year. } \\
\text { Additional positions for } \\
\text { their PL brand. }\end{array}$ & $\begin{array}{l}\text { Additional accent on } \\
\text { their own brands. } \\
\text { Effective details aligned } \\
\text { with the strategic } \\
\text { objectives at brand } \\
\text { level encourage } \\
\text { shopping. }\end{array}$ & $\begin{array}{l}\text { Reminding of, } \\
\text { informing about, and } \\
\text { representing brands/ } \\
\text { products in an easy and } \\
\text { attractive manner. }\end{array}$ & $\begin{array}{l}\text { The ,right" kind of additional } \\
\text { positions in the ,right" shop } \\
\text { aisles for the „right" brand } \\
\text { that meets the needs of } \\
\text { targeted customers. }\end{array}$ \\
\hline
\end{tabular}

Source: Shankar, 2011, 28-29

without any real increase in the overall consumption or even to the detriment of the overall results of the retail facility.
On the other hand, the absolute favoring of products of a private brand can cause problems to the retailer. Namely, as a rule, shoppers oriented towards branded 
products boycott offers aspiring to rapidly substitute the established brands, which may potentially create their dissatisfaction by an unbalanced offer of private brand products. Hence the conclusion that there is a long-term problem of disharmony between retailers and suppliers (Stojanovic, Filipovic \& Stojkovic, 2014).

Shoppers, above all, wish to meet their needs in an efficient manner, with a good shopping experience they intend to repeat. A disharmony between retailers and suppliers may bring short-term benefits to the shopper, but also a certain disappointment with respect to the expectations they have already developed. Unsustainable offers at retail stores do not bring long-term customer satisfaction and shopper loyalty.

Shopper marketing is a business process which, based on its essential shopper insights, implies a joint retailer-manufacturer business process. Retailers" and manufacturers" information and expertise require that they should be united so that their view on shoppers could be comprehensive. Separate interests and sales promotion activities by means of shopper marketing often lead to conflicting business effects in the long term. Hence the complexity of the formulation of shopper marketing balanced measures, without which it is impossible to obtain a clear picture of what is actually achieved by individual activities activating sales in the store.

By systemizing the findings of the leading authorities in the field of shopper marketing, P. Silveira and K. Marreiros (2014) give a transparent demarcation of the expected benefits from shopper marketing as an innovative business practice:

- Shopper - Potential benefits of shopper marketing: the product, the service, shopping experience, and communication tailored to the shopper. Relevance and acceptability.

- Retailer - Potential benefits of shopper marketing: improved customer satisfaction, in addition to higher sales and differentiation, leading to greater loyalty and recommendation. More efficient category (assortment) management, the retail space planning and relationships with suppliers.
- Supplier - Potential benefits of shopper marketing: the brand value strengthening; a more effective brand activation at the time of purchase; the identification of the key points of contact and stimuli for an effective bigger interaction with the shopper; an increase in loyalty and sales; and a deeper relationship with the retailer.

The overview of the possible benefits of shopper marketing leads to the conclusion that the mission of the business strategy is to stabilize relations in marketing channels, i.e. to reach a consensus between retailers and suppliers that the interest of the shopper is the primary objective of mutual cooperation and integration. Improving the shopping experience of shoppers in a retail store, based on the good knowledge of their interests and behavior, provides better sales results for both the retailer and the supplier, enabling them, at the same time, to achieve the objectives of the strategic positioning of their brands on the basis of closer and more committed cooperation. It should be noted that shopper marketing is an interest of particularly importance for supplier organizations, because through this strategy, they approach retailers and develop a deeper relationship and safer cooperation with them.

The challenge of shopper marketing is to shift the business focus from the consumer to the shopper and to develop adequate knowledge and skills that are more adequate for the new business strategy. The assumption of shopper marketing is the changing of corporate culture in companies by means of organizational and procedural solutions enabling the implementation of the new approach. The traditional approach to marketing in retailer and supplier organizations by its nature poses an "obstacle to the rapid acceptance and implementation of shopper marketing, including the challenge of developing new knowledge, plans, and fieldwork, in function of the shopper and a better shopping experience.

A systematic review of potential problems in the implementation of the shopper marketing concept includes the following elements (Silveira \& Marreiros, 2014):

- A lack of information about and research in the shopper's behavior, along with the complexity 
of understanding shoppers and a hampered predictability;

- The technical problems and cost of shopper insight structuring in a variety of retail formats;

- A difficult shift in the focus from the consumer to the shopper and creating offers and messages irrelevant to the shopper;

- A lack of qualified managers for shopper marketing;

- A lack of shopper marketing reference measures and the traditional evaluation of shopper marketing activities;

- Traditional processes of communication, resources allocation and the organizational structure based on assumptions;

- Problems of the alignment of retailers and suppliers in the field of the strategy and tactics and solutions beneficial to all three parties; and

- Suppliers focused on short-term solutions and the sale of products.

In order for shopper marketing to have a good basis in retail and supply organizations, all traces of possible deficiencies of traditional business should be eliminated. Shifting the focus from the consumer to the shopper means new knowledge and skills, with adequate measures of results. The retailer and the supplier should establish a joint shopper insight, which would be the basis of the partnership development of goals, plans, and procedures of operationalization of the tasks to develop relationships with shoppers. The development of new plans and activities of work supervision, with elements of the continuous improvement of activities and results, is also an integral part of new business processes.

\section{A PARTNERSHIP IN THE CATEGORY MANAGEMENT FOCUSED ON THE SHOPPER}

The business process of shopper marketing can be an integral part of category management (Bogetić,
2007) - namely, of the active approach to a particular brand placement, or a particular supplier of a retail facility. Encouraging sales of a brand within shopper marketing activities thus represents a part of a wider range of promotional activities for the assortment in a sales facility. The sales promotion plan of the category assortment may, thus, be composed of a series of partial plans for shopper marketing at the level of individual items, i.e. brands. The result is a balanced promotional sale in a store, taking into account the achievement of the business objectives defined at the level of items, categories, and the store in general.

The business process of category management focused on the shopper has its own specifics and defining moments that potentially make it shorter, faster, and more effective. Shopper insights are the framework for the formulation and improvement of the business process of category management, with the aim of achieving effective and sustainable sales of the category assortment as a whole and at the level of individual brands.

At the beginning of the business process of category management illustrated in Figure 1, shopper marketing needs to answer the question of whether the category content is clear and functional from the standpoint of the shopper profile, the needs settled and the profile of the store. The retailer has to define the category in accordance with target shoppers and the requirement of the purchasing mission realized in the store, with the imperative of the assortment and promotional activities efficiency in a specific situation. The supplier, on the other hand, adjusts the offer to the specific sales situation, primarily by developing an appropriate marketing mix for an active sale in the store.

The starting point of shopper marketing at the point of sale is to clarify the profile of the shoppers of the retail store and their behavior in the shopping process. The questions: Who are the most active shoppers in the store? Which needs are being met? What is the required retail service? and What business opportunities are unused? are the starting point of a retail analysis at the level of each category of products. Through shopper marketing, the retailer promotes the results of the store sales and specific categories as well as the results of individual products for which the business plan is 


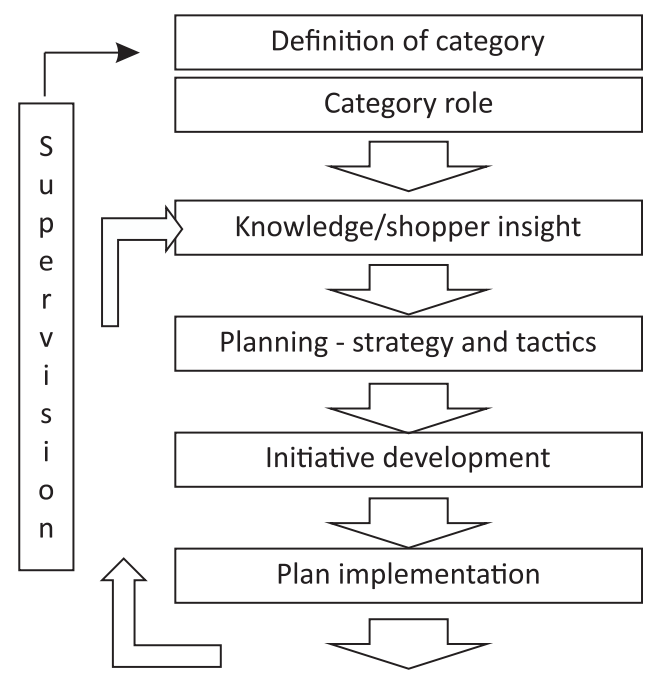

Figure 1 The business process of category management focused on the shopper

Source: Fowler \& Goh, 2012, 104

devised and implemented. The knowledge of target shoppers, requested products and categories provides retailers with a valuable negotiating authority in relation to prospective suppliers. This improves relations with suppliers, as well as category assortment (Silveira \& Marreiros, 2014).

For the supplier, on the other hand, shopper marketing brings the focus on retailers and retail stores that are the most important for target shoppers with specific needs in different situations. In this situation, the supplier spots the key points of contact with shoppers and defines effective communication channels. The result is a formulated action plan to activate customers in the function of easier shopping and its repetition. The offer as well as store space management are thus more efficient.

A comprehensive model of the category management business process focused on the shopper is defined in seven steps and is focused on the shopper (see the previous illustration). The model includes: the category definition, the category role, a shopper insight, a strategic and tactical plan, implementing the plan, and the monitoring and correction of the category management implementation strategy. In order for the service to be efficient and effective, the key moment of this business process is to actively use shopper insights collected within loyalty programs or another customer relationship management (CRM - Customer Relationship Management) approach (Marinkovic \& Senic, 2012).

The focus of the steps of the business process of the defining and determining of the category role is placed on significant compliance with the retail strategy and key (destination) categories. When the defining of the category and its role is finished, the work is only reviewed in exceptional cases, thus speeding up the process of the innovation and adaptation of operational activities at the level of the category. Two steps of the business process of category management are thus completed, whereas operative work on the placement of category assortment remains continuous.

The central part of the innovated business processes, therefore, also includes the following: supervision or control and development; shopper insight generating; strategic planning; tactical planning; initiatives with suppliers; a plan implementation; and the continuity of the supervision of category management. The focus is on the rapid use of opportunities related to a category, at the level of shoppers' behavior and their satisfaction.

Generating a shopper insight implies answering the questions about the retail environment, including the following: consumers and shoppers; products and services; retailers and competitors; shopper loyalty; and the retail market as a whole. The aim is to gain a fundamental understanding of shopper behavior and include the knowledge of shoppers in the business process of category management, with the effect of the product category assortment and presenting, appropriate for the store and the associated modalities of shopping. Thus, for example, it is often necessary to improve the structure and amount of the offered assortment of categories, since overcrowding the store with goods needlessly frustrates shoppers, who have clear reasons for visiting the store. Objectivized information about shoppers is the presumption of good decisions on product assortment and other elements of the offer in the store. 
Emphasizing the focus on the shopper should simultaneously lead to the strategic and local positioning of the retailer at the category level. In the end, the retailer should have a developed offer appropriate for the specific shopper in the store, simultaneously achieving wider corporate objectives.

The dynamism and attractiveness of the category of the assortment offer in the store is achieved when the retailer treats certain segments of the assortment differently, defining different, yet compatible goals he wishes to achieve. In that manner, one part of the category assortment may attract customers in a retail facility, thus generating traffic, while the other part of the category assortment can be developed to generate cash. Additionally, with the assortment, the retailer can also achieve the following objectives: create excitement in the store; improve the price image; generate a profit; promote values of transactions; generate protection from the competition; and improve the image of the selected store (Bogetić, 2007, 148). Innovative objectives to be achieved at the level of categories also include the following (Fowler \& Goh, 2012, 104-105): an ease of shopping within categories (an easy communication approach); shopping large quantities or packages (a transaction approach and cross merchandising within a category); shopper enthusiasm (an approach to customers who are loyal and not driven by cost); an opportunity to shop (tasting approach); and the development of new shoppers of a brand (the focus on selected customer segments). The presented aspects of potential roles of category assortment segments indicate that there are great opportunities for creative combinations and differentiations of the overall supply.

After defining the strategic and tactical category plan, a retailer develops a wide partnership initiative, which is a prerequisite for the business plan realization. The differentiation and competitive advantage at the category level require a quality partner with adequate capacities. The retailer now needs to perform a fundamental analysis of available procurement alternatives and define priorities. In this process, the retailer chooses suppliers with whom he/she will realize balanced programs of shopper marketing at the level of selected product categories, simultaneously respecting the objective of the improvement of business results measured at the category level and through overall store performance (Shankar \& Bolton, 2004).

The plan of the category management program implementation should be detailed, both at the level of upgrading the sales promotion activities portfolio and with respect to the realization of cooperation with selected suppliers. This also implies the partners' compliance in all elements of the business plan, thus allowing for a balanced operationalization of tasks and achieving good, harmonious results. The implementation of a business plan developed for a category of products significantly relies on the continuous process of monitoring or supervision, which enables even "on-the-fly" corrections and the improvement of category management. This further improves the efficiency and effectiveness of category management, with a faster and better service for shoppers.

Shopper marketing varies by categories, as determined by their nature, i.e. the manifested profile of demand and shopping patterns. A good illustration of the shopper marketing dynamics of various products categories is the difference between durable and nondurable consumer goods, as well as the difference between relevant shopper marketing practices. In this respect, it is necessary to consider the likelihood of planned or unplanned shopping according to the nature of the aforementioned categories and profile of their shoppers (Inman, Winer \& Ferraro, 2009).

Comparing to non-durable consumer goods, durable goods have a longer cycle of product exploitation, and many involve a longer seeking process, for which reason their shopping cycle is longer. Furthermore, shopping lists for most non-durable consumer goods are principled in character and contain category names (e.g. meat, milk, detergent, candy); so, brand names and the present substitutability are relatively neglected; hence, it is an important goal for manufacturers to make their brands ",appear" on your shopping list.

The presence on the shopping list is a priority for manufacturers of durable goods, where demand is significantly defined by brands, so it is of utmost importance for the supplier that his/her brand should be on the shopping list "carried around" by 
the shopper. Social networks and social media have a significant role in the shopping cycle of such and other goods with a longer shelf life. A word-of-mouth communication and the transfer of brand-related experiences significantly impact a brand's reputation and demand. Shopper marketing pays special attention to this aspect of brand demand.

Shopper marketing tactics appropriate for different product categories differ to the extent to which the nature of shopping and the shopper behavior also differ. Thus retailers of durable goods often use shopin-shop solutions to differentiate the offer, facilitate the process of "finding their way" for shoppers, and encourage shopping. Department stores are particularly active in this field, always looking for a space for business innovations and survival in an ever-growing competition. The transformation of a retail facility in JCPenney's department stores into a collection of shop-in-shop operations is just one example (Bhasin, 2012). In addition to the shop-inshop concept, due to the complex process of shoppers' decision making, in an effort to prolong the visit and increase the probability of shopping, retailers in durable goods often make it easier for the shopper to stay at the point of sale by providing care for their children, offering a coffee-break space, and the like.

\section{MONITORING THE PERFORMANCE OF JOINT WORK ON SHOPPER MARKETING}

As we have previously mentioned, shopper marketing requires a much deeper cooperation between suppliers and retailers than it was the case in traditional marketing. The fields of activity spread over several functions or several processes, which broadens and deepens the horizon for monitoring effects of this new approach to marketing. In order to monitor effects of shopper marketing, first, it is necessary that common goals should be set, and then measures for achieving these goals established. For this purpose, lists of results (scorecards) are proposed, which comprehensively present results of shopper marketing from the following three perspectives: the enterprise perspective (Corporate Shopper Marketing Scorecards), the retailer's product category perspective
(Category Scorecard), and the supplier's perspective (Account Scorecard) (GMA \& Deloitte, 2008). The list of shopper marketing results at the enterprise level monitors the progress of the implementation of this strategy, whereby the key performance indicators at the category level and at supplier level are summarized. Category managers use this list of results at the level of the category to get an insight into how marketing contributes to results of the product category. Suppliers use their list of shopper marketing results to monitor effects of shopper marketing on the achievement of objectives in relation to retailers, as well as to monitor satisfaction (the realization of interests) of their retailer partners. Suppliers should incorporate this list into their list of objectives defined in their own marketing and sales strategies.

However, regardless of partners' firm will in shopper marketing, the practice of measuring effects of this strategy has not yielded an unambiguous and fully established set of criteria. Moreover, research shows that both retailers and suppliers recognize the importance of this practice for their cooperation, but also point out that the effectiveness of cooperation between partners in this regard is quite low (GMA \& Deloitte, 2008, 25). Leaders in shopper marketing, retailers and suppliers, are usually focused on sales, profits, the market share (by category), the number of shoppers (per segment), activities before entering the store, the number of visits to stores, spending per visit, and the number of purchased products in the shopper basket (KIE Square, 2015). Consequently, the implication is that opportunities for the improvement of shopper marketing metrics are large, i.e. it is a field very suitable for innovation. In this context, the following metrics, among other things, which measure the following, are proposed: the shopper's attention and consideration while shopping (the closeness of shoppers in relation to the product, the time of concentration on the product, touched/examined products); the nature of decisions (planned versus unplanned, frequent versus infrequent, hedonistic functional shopping); and intermediate effects (effects of shopping one category products on the shopping of another category products). In this sense, possibilities provided by new methodologies are used, and include biometrics (for example, cardiac monitoring), cameras 
monitoring movements of the eye and the body etc. The biggest challenges are certainly those in linking shopper marketing metrics with the value for owners, namely shareholders (Shankar et al, 2011).

The practice of measuring shopper marketing effects has evolved over time, and some of the criteria that most closely represent the achievement of partners' profitability goals have been imposed over time. There have always been challenges in monitoring effects of investment in marketing, and such challenges are also present in this case. What is certain is that shopper marketing programs should contribute to the growth of sales of suppliers' branded products, customer satisfaction, along with the growth of sales and profits for retailers. However, the development of the measurement system in shopper marketing should not only focus on the transaction, but also on the shopper's behavior and their attitudes as well. In this way, a wider area of shopper marketing measurement is obtained. Figure 2 illustrates the field of measurement, retailers' and suppliers' goals and objectives that are in accordance with the preceding paragraphs.

Figure 2 indicates that the realization of the shopper marketing objectives should have a positive effect on ROI (Return on /Marketing/ Investment), the growth of the sales volume, an increase in productivity and so

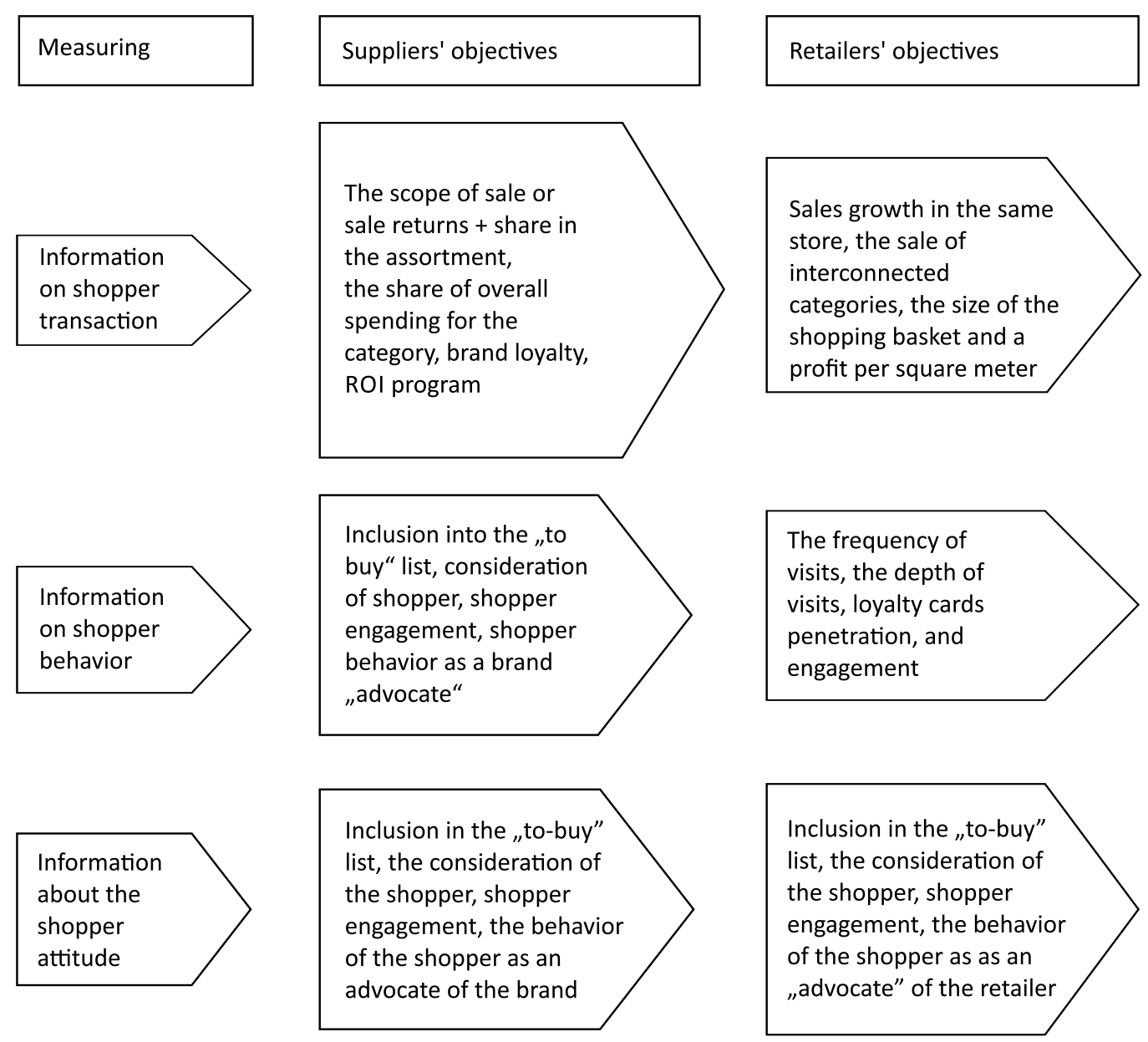

Figure 2 A comprehensive program of shopper marketing measurements 
on. The ultimate goal of shopper marketing is clear. It aims to create value for shoppers and value for owners of retail and supply companies.

Increasing customer satisfaction in the store contributes to their perception of values obtained, whereby their willingness to pay a higher price (willingness to pay) is also increased. Also, the shopper's positive attitude accelerates his/her decision to buy, leading not only to an increased, but also rapid outflow of cash toward the retailer, while reducing the risk that they will "miss" the shopping which is planned by the shopper marketing program, whereby the likelihood of shopping actually increases. This has a direct impact on maximizing the value created for the retailer. Increased and accelerated cash flows are transferred to suppliers of branded products, which directly affects the value created for partners in the process of shopper marketing. The logic of creating value for shoppers, retailers and suppliers of branded products is shown in Figure 3.

Based on the presented Model of a Partnership to Create Value in Shopper Marketing, illustrated in Figure 3, it may be concluded that the shopper marketing process is a powerful and controllable instrument for creating value for customers and business owners involved in the process. The developed model of partnership in creating value in shopper marketing suggests the effectiveness and sustainability of the business concept and cooperation in marketing channels developed on such grounds.

\section{THE INSTITUTIONALIZATION OF COOPERATION AND THE FUTURE OF SHOPPER MARKETING}

Essentially, shopper marketing presents a partnership business initiative, as evidenced by institutionalization in its own kind of cooperation in the development of the concept. The Retail Commission on Shopper Marketing Initiative, for example, is a representative illustration of the strategic alliance of leading marketing institutions, which has been working on developing the shopper marketing concept since 2009. The key organizations involved in this initiative are Coca-Cola Company, In-Store Marketing Institute, and Partnering Group (Shopping Marketing Best Practices, 2010). The importance of institutional cooperation for shopper marketing is also illustrated by the research and consulting activities of the Food Marketing Institute/FMI (The Voice of Food Retail) and Grocery

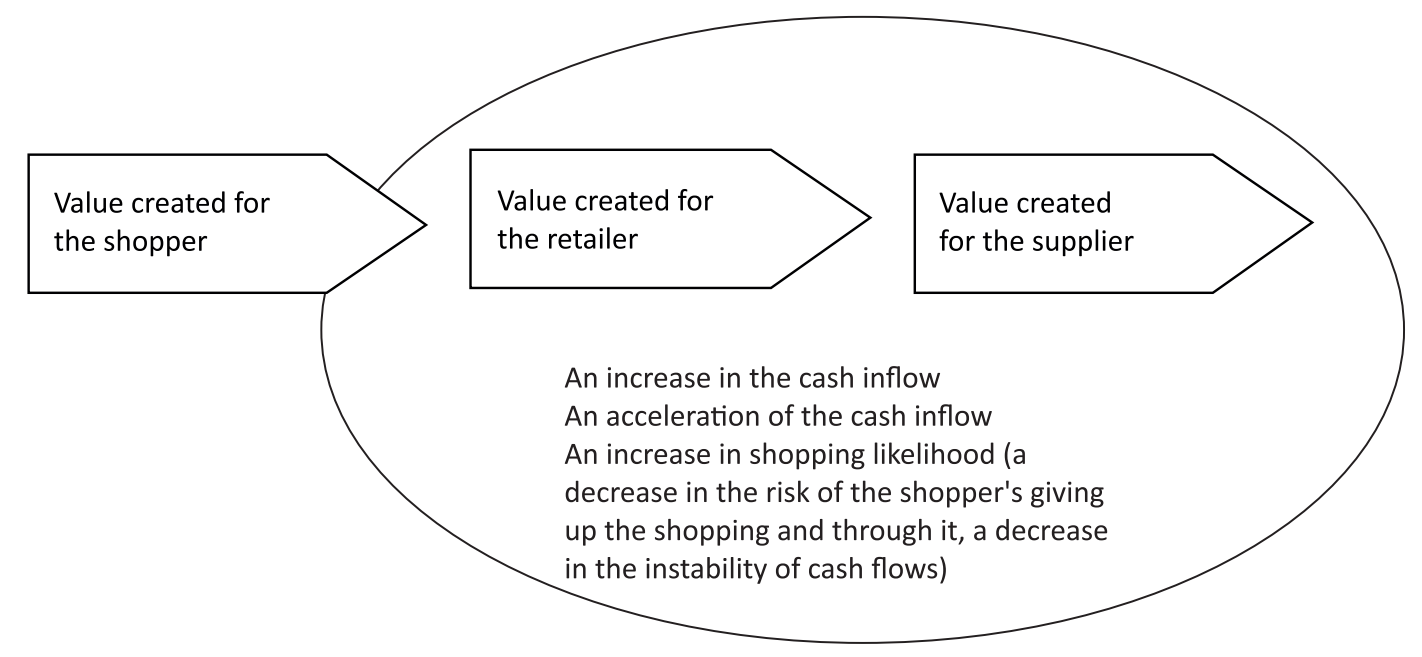

Figure 3 A model of a partnership to create value in shopper marketing 
Manufacturers Association/GMA (The Association of Food, Beverage and Consumer Products Companies) (FMI 2015 GMA and Deloitte 2015). For example, in 2015, the FMI has combined the interests of 1,225 retail and wholesale companies worldwide in the field of research and education, including the analysis of the activities of 40,000 retail stores and 25,000 pharmaceutical operations. IELKA (The Institute of Retail and Consumer Goods-GR) is also an association promoting the institutional cooperation of the 6 key retail chains in Greece in the field of research and the promotion of positive retail practice (IELKA, 2013).

The growing institutionalization of cooperation in shopper marketing is also related to the expansion of the research field related not only to the aspects of traditionally observed competition, but to increasingly active multichannel type competition as well. The growing networking of the modern shopper, who uses multiple channels of information and searches during the shopping cycle, continually opens up new questions and possibilities of shopper marketing. The shopper's motives, the process and the shopper's triggers for shopping in a multi-channeled business environment are becoming a preoccupation of both retailers and suppliers.

The likelihood of shopping and the overall shopper value increases when they collect information and make decisions by using mobile platforms (Ansar, Mela \& Neslin, 2008). Hence the development of a multi-channel management of its own kind and the related strategy and tactics of shopper marketing focused on very specific and demanding aspects of attracting, retaining and developing relationships with shoppers (Neslin, Grewal, Leghorn, Shankar, Teerling, Thomas \& Verhoef, 2006). The business process focused on multi-channeled shoppers (Neslin \& Shankar, 2009), appropriately structured and selected (Kushwaha \& Shankar, 2007), becomes sui generis partner preoccupation of retailers and suppliers. At the same time, a harmony between offers in various channels, including the price and the overall shopper experience (Kushwaha \& Shankar, 2009), is the most difficult to achieve.

The ratio between the importance of the impact on the shopper inside and outside the store is changing with time. According to some newer researches, the traditional store is no longer as important for making shopping decisions as it used to be. More and more shoppers make decisions outside the store (Neff, 2009). According to some studies, only $30 \%$ of the actual shopping decisions are generated in store aisles and on shelves (Angrisani, 2015). These findings suggest a conclusion about a prolific perspective for research into impact on the shopper outside the traditional retail stores.

Along with shopper marketing, the theory of retail management and marketing is being developed, including new terminology. The starting point for developing new terms is, for example, the method of obtaining information and the very act of shopping in conditions of multi-channel informing and decision making, which constitutes a "hybrid shopping" (Kalyanam \& Tsay, 2013). This is also how the term boomerooming appeared, among others, which denotes the shopper's research activity on the Internet (Shankar \& Kushwaha, 2010), followed by checking information in the store and the very act of online shopping (Boomerooming, 2015). Shopping in an actual traditional store (Verhoef et al, 2007) shall cease to be the modern shopper's priority.

Traditional business theory and practice almost exclusively deal with the shopper's visit to the store (Shankar et al, 2010). Modern business based on mobile technologies and multichannel options for obtaining information and choices implies a shift from the traditional view of retail. The well-known retailers Macy's and Best Buy, for example, provide applications for iPhone and Android devices, through which they detect and attract customers in nearby shops. The social mapping services and Loopt and FourSquare Labs applications also have a similar function (Fowler, 2010).

Besides improving standards of shopping, mobile devices allow retailers to "visit" the shopper environment, thereby actively working on stimulating and promoting sales (Shankar et al, 2010). Partnership co-operation between retailers and suppliers in shopper marketing will eventually develop in the direction of studying the concept of retailers' entering the shoppers' environment, including the width and 
depth of the challenge of developing appropriate approaches for different situations identified (Fowler, 2010). There is no doubt that achieving a balance in each other's mutual visits by customers and retailers with adequate metrics of good results for both parties is a promising and very important issue.

The defining of the shopping process is a sensitive issue for retailers and suppliers (Hoyt, 2006) in a multichannel environment, including moments of the transformation of the consumer into the shopper, and vice versa, with an emphasis on traditional and contemporary business practices. Developing a new viewpoint on purchase triggers in ",brick-andclick" shopping situations, with an emphasis on the sustainable rationality and synchronizing of stimuli and influences, will include a new consensus on the shopper insight at the level of a particular brand and retail situations.

The future of partnerships in shopper marketing will certainly be additionally determined by a new understanding of interests and the redefining of business processes in conformity with the consensus and demands of new solutions. The prospect of achieving the task of bringing benefits to all three parties (the customer, the retailer, and the supplier) involved will further become challenging with redefining the position and role of marketing channels and with new ambitions of the participants in shopper marketing. New moments in retail organizations' behavior in the shopper environment will represent new opportunities and challenges for suppliers who are developing innovative approaches to brand management.

Before developing new aspects in multi-channel marketing, the retail and supply partners must deal with the requirement for the clear positioning of shopper marketing in traditionally observed organizations. It is necessary to delineate responsibilities for shopper marketing with respect to traditional organizational solutions in an actual moment so that the demanding organizational structure would be efficient and effective. The starting point of new structures is certainly the missing developed standards of shopper marketing practice, with delineated responsibilities and job descriptions, for which skills have been defined. For shopper marketing practices to move forward in the direction of using the potential of mobile platforms and a multichannel business partnership, it is necessary that these and other basic issues of crucial importance for the efficiency and effectiveness of the improved treatment of shoppers should be clarified and resolved (Hoyt \& Swift, 2014).

\section{CONCLUSION}

Beside additionally shedding light on the strategic importance of shopper satisfaction and their careful treatment by suppliers and retailers, the conducted research into the partnership perspective of shopper marketing points to the key aspects of the harmonization of relationships in marketing channels with respect to shopper marketing. The research points to the elements of the efficient offer and an efficient customer service, by emphasizing the necessity of a systematic retailer-supplier partnership on comprehensive customer care in all the steps of the shopping process. Having in mind their importance, the adaptability and availability of the offer, as well as the critical importance of the profiled and balanced activity of sales promotion, have been emphasized in the research.

The contribution of the research also reflects in the clear identification of the fundamental problem of the implementation of shopper marketing, contained in the challenge of changing the business focus from the consumer to the shopper, while also including issues of business culture and the profiling of the strategy, new business processes, positions and responsibilities. On the one hand, these challenges are internal in character, whereas, on the other, they are also becoming interorganizational in character, especially with respect to the harmonization of acting in a partnership and the effectiveness of shopper marketing.

By the redefining of the business focus in the direction of understanding the shopper and shopper satisfaction as the starting point, the paper paves the way for a new logic of category management, which is traditionally oriented towards the consumer in a retail store. In 
this regard, the two key innovations are suggested in the product category management strategy and tactics: first, shoppers and shopper insights are the new starting point of category management. Second, a foundation has been laid for dividing the business process into two separate components - the strategic and the operative ones. The strategic component - the defining of the category and its role - is not the subject of continuous consideration and revision. On the other hand, an intensive operative activity of category management is suggested at the level of shopper insights, business planning and the realization of plans, supervision and the development of the business process. Thereby, saving time and other resources is achieved, while category management efforts are efficiently focused on improving the shopping experience with respect to the store, the category and the brand.

By establishing more efficient, shopper-oriented category management as an umbrella business concept, the starting point for the development of appropriate metrics for shopper marketing business results has been formulated. Starting from the multi-functional and multi-process character of shopper marketing, the paper also clarifies the widening and deepening of the horizon for business results measurements. In this regard, the conducted research defines the Model of Partnership to Create Value in Marketing Channels. It is actually a dynamic view on the list of results, at the levels of transactions and shopper behavior, and it is appropriate in the context of shopper marketing progress.

The described research results have undoubtedly confirmed the starting hypothesis: „Effective and efficient shopper marketing is based on a balanced partnership between retailers and suppliers, and this partnership is supported by improvements in product category management and adjustments in performance metrics." The conclusions on the institutionalization of shopper marketing co-operation speak in favor of the stated claim, which represents a new and insufficiently explored paradigm of competition and marketing channels co-operation.

The aspect of a profiled partnership on shopper marketing is especially prominent in multi-channel business operations, where it is especially challenging to achieve a harmonious offer. Hybrid shopping on mobile platforms and a volatile impact on shoppers and their behavior represent the current and promising field for doing research into collaboration between retailers and suppliers.

In addition, the standardization of the shopper marketing approach is still an open scientific and practical issue of shopper marketing. Theory and practice have not yet sufficiently clarified an efficient way for accepting and implementing the shopper marketing strategy and tactics, with clear internal and inter-organizational definitions of the position, knowledge and skills. Teamwork in the conditions of the traditional orientation towards the consumer and a new emphasis on the coexistence of shopper values is also a promising field for conducting investigation into the implementation of shopper marketing.

The shopper marketing concept is also undoubtedly attractive in the domestic business environment characterized by internationalization and concentration in marketing channels as well as by limitations manifested as a lack of valid records of business practice. On the one hand, there are some shopper marketing programs promoted by individual multinational companies. On the other hand, it is unclear whether domestic companies practice shopper marketing at all. Moreover, skepticism with respect to new marketing implementation is well-justified in the conditions when even the implementation of traditional marketing is problematic. Still, clear positive effects of shopper marketing and the successful business practice of leading international companies doing business on the domestic market are expected to inevitably lead to the spreading and improving of shopper marketing practice with both domestic retailers and suppliers, for the common benefit of both retailers and suppliers, and above all of the shopper, too.

\section{REFERENCES}

Angrisani, C. (2015). Study: Shopper marketing spending doubles. Retrieved October 26, 2015, http://supermarketnews. com/marketing/study-shopper-marketing-spendingdoubles\#ixzz3VEeI9Shq 
Ansari, A., Mela, C. \& Neslin, S. (2008). Customer Channel Migration. Journal of Marketing Research, 45(1), 60-76. doi: 10.1509/jmkr.45.1.60

Bhasin, K. (2012). Macy's Quietly Recognizes That JCPenney CEO Ron Johnson Might Be On To Something. Retrieved October 29, 2015, http://www.businessinsider.com/jcpenney-ronjohnson-shop-in-shop-2012-9

Bogetić, Z. (2007). Menadžment kategorije proizvoda. Beograd, Republika Srbija: Data Status, CID Ekonomskog fakulteta Univerziteta u Beogradu.

Bogetić, Z. i Petković, G. (2014). Kako pripremiti trgovinsko poduzeće za shopper marketing? U N. Knego, S. Renko, i B. Knežević (Ur.). Perspektive trgovine 2014: Ljudi, tehnologija, znanje (str. 140-154). Zagreb, Hrvatska: Ekonomski fakultet Univerziteta u Zagrebu.

Boomerooming - Bad News for Bricks and Mortar Retailers (2014). Retrieved October 11, 2015, https://www.redsnapper. net/boomerooming

Buckler, S. A., \& Zien, K. A. (1997). The Spirituality of Innovation: Learning from Stories. Engineering Management Review, 25(4), 89-102.

Egol, M., Sarma, R., \& Sayani, N. (2013). Reimagining shopper marketing: Building brands through omnichannel experiences. Strategy \& pwc, 10. Retrieved October 19, 2015, http://www.strategyand.pwc.com/global/home/what-wethink/reports-white-papers/article-display/reimaginingshopper-marketing

Fam, K. S., Merrilees, B., Richard, E. J., Joysa, L., Li, Y., \& Krisjanous, J. (2011). In-store marketing: a strategic perspective. Asia Pacific Journal of Marketing and Logistics, 23(2), 165-176. doi:10.1108/1555851111120470

FMI, (2015). U.S. Grocery Shopper Trends 2015- Executive Summary. Retrieved November 10, 2015, http://www.fmi. org/docs/default-source/document-share/fmitrends15-execsumm-06-02-15.pdf?sfvrsn=2

Fowler, G. A., (2010). Retailers Reach Out on Cellphones: Software Apps Lure Shoppers with Rewards, Coupons and Product Information. The Wall Street Journal, 21, B6.

Fowler, D., \& Goh, B. (2012). Retail Category Management. New Jersey, Columbus: Pearson Education.

Gilbride, T. J., Inman, J. J., \& Stilley, K. M. (2013). What Determines Unplanned Purchases?: A Model Including Shopper Purchase History and Within-Trip Dynamics. Wharton School - University of Pennsylvania. Retrieved October 18, 2015, https://marketing.wharton.upenn.edu/mktg/ assets/File/Dynamic\%20Effects\%20in\%20Unplanned\%20 Purchase\%20Behavior\%202-18-13.pdf
GMA \& Deloitte, (2008). Delivering the Promisse of Shopper Marketing: Mastering Execution for Competitive Advantage. Retrieved November 10, 2015, https://www.gmaonline. org/downloads/research-and-reports/GMA-Deloitte_ ShopperMktReport_FINAL.pdf

Goldberger, N. (1990). Notes on qualitative research. The Fielding Institute, Santa Barbara, CA.

Guglielmi, K. A. (2000). Crisis Induceced Learning in a Small Business: A Case Study. Unpublished doctoral dissertation, University of Connecticut, Storrs, Connecticut, United States.

Hoyt, C. (2006). Shopping for Consumers. Retrieved November 27, 2015, http://hubmagazine.com/archives/the_hub/2006/ may_jun/the_hub12_hoyt.pdf

Hoyt, C., \& Swift, N. (2014). Up, Up \& Away. The Hub, July/ August, 42-45. Retrieved November 10, 2015, http:// hubmagazine.com/archives/the_hub/2014/jul_aug/the_ hub61_hoyt.pdf

IELKA, (2013). Productivity and Efficinecy in Grocery Retail. Retrieved November 11, 2015, www.ielka.gr

Inman, J. J., Winer, R. S., \& Ferraro, R. (2009). The Interplay Among Category Characteristics, Customer Characteristics, and Customer Activities on In-Store Decision Making. Journal of Marketing, 73(5), 19-29. doi: http://dx.doi.org/10.1509/ jmkg.73.5.19

Interbrand - The science of shopper insights (2015). Retrieved October 9, 2015, http://www.interbranddesignforum.com/ wordpress/category/shopper-sciences/

Kalyanam, K., \& Tsay, A. A. (2013). Free riding and conflict in hybrid shopping environments: Implications for retailers, manufacturers, and regulators. The Antitrust Bulletin, 58(1), 19-68.

Kapferer, J. N. (2008). The New Strategic Brand Management. London, UK: Kogan Page.

Khuller, M. (2013). Shopper Marketing's ROI. ADMAP.

KiE Square Perspective. Analytic driven competitive edge in shopper marketing. Retrieved November 20, 2015, http:// www.kiesquare.com/shoptalk/pdf/KiE\%20Square\%20 Perspective_Analytics\%20Driven\%20Competitive $\% 20$ Edge\%20in\%20Shopper\%20Marketing.pdf

Kushwaha, T. L., \& Shankar, V. (2007). Optimal Allocation of Marketing Efforts by Customer-Channel Segment. Marketing Science Institute, 07-207. Cambridge, Massachusetts.

Kushwaha, T. L., \& Shankar, V., (2009). Are Multichannel Customers Always the Most Valuable Customers? An 
Empirically Generalizable Multicategory Analysis. Working Paper. North Carolina: University of North Carollina, Chapel Hill.

Marinkovic, V., \& Senic, V. (2012). Analysis of service quality elements in corporate banking. Economic Horizons, 14(1), $15-$ 24. doi:10.5937/ekonhor1201013M

Marshal, C., \& Rossman G. B. (1995) Designing Qualitative Research. Sage Publications, Thousand Oaks.

Mesihović, N. (2003). Uvod u metodologiju društvenih nauka. Sarajevo, Bosna i Hercegovina: Ekonomski fakultet.

Mucchielli, A. (1996). Dictionnaire des methodes qualitatives en sciences humaine et sociales. Paris, Francia: Armand Colin.

Neff, J. (2009). Trouble in Store for Shopper marketing? Advertising Age, 80(8), 3-32.

Neslin, S. A., Grewal, D., Leghorn, R., Shankar, V., Teerling, M. L., Thomas, S. J., \& Verhoef, C.P. (2006). Challenges in Multichannel management. Journal of Service Research, 9(2), 95-113.

Neslin, S. A., \& Shankar, V. (2009). Key Issues in Multichannel management: Current Knowledge and Future Directions. Journal of Interactive Marketing, 23(1), 70-81. doi:10.1016/j. intmar.2008.10.005

O'Leary, N. (2013). Shopper Marketing Is Going MainstreamRetail is the center of gravity. Adweek. Retrieved November 5, 2015, http://www.adweek.com/news/advertising-branding/ shopper-marketing-going-mainstream-149630

Petković, G., \& Bogetić, Z. (2014). Different perspectives of the retail marketing development. In N. Janićijević (Ed.). Contemporary Management and Marketing Methods in Improving Competitiveness of Companies in Serbia in the Process of its Integration in European Union (pp. 105-118). Belgrade, Republic of Serbia: CID of The Faculty of Economics University of Belgrade.

Pincott, G. (2012). Point of view on shopper marketing. In M. Stahlberg, \& V. Maila, (Eds.). Shopper Marketing: How to Increase Purchase Decisions at the Point of Sale, 2nd ed. (pp. 9-12). London, UK: Kogan Page.

Revolutionary In-Store Insights: Endcap Displays and the Shopper, from the Category Management Association, (white paper). How Are Shoppers Reacting to Endcap Displays? Retrieved October 25, 2015, http://www.shoppertech.org/ CM021315.html. Retrieved October 28, 2015, from http:// www.videomining.com/
Shankar, V. (2011). Shopper Marketing. Cambrige, Massachusetts: Marketing Science Institute.

Shankar, V., \& Bolton, R. (2004). An Empirical Analysis of Determinants of Retailer Pricing Strategy. Marketing Science, 23(1), 28-49. doi: 10.1287/mksc.1030.0034

Shankar, V., \& Balasubramanian, S. (2009). Mobile Marketing: A Synthesis and Prognosis. Journal of Interactive Marketing, 23(2), 118-129. doi: 10.1016/j.intmar.2009.02.002

Shankar, V., Alladi, V., Hofacker, C., \& Naik, P. (2010). Mobile Marketing in the Retailing Environment: Current Insights and Future Research Avenues. Journal of Interactive marketing, 20(2), 111-120. doi: 10.1016/j.intmar.2010.02.006

Shankar, V., \& Kushwaha, T. L. (2010). An Empirical Analysis of Cross-Channel Effects in a Multichannel Environment. Working Paper, College Station: Texas A\&M University.

Shankar, V., Inman, J. J., Mantala, M., Kelley, E., \& Rizley, R. (2011). Innovations in Shopper Marketing: Current Insights and Future Research Issues. Journal of Retailing, 87 (Supplement 1), 29-42. doi:10.1016/.retai.2011.04.007

Shopper Marketing Best Practices: A Collaborative Model for Retailers and Manufacturers. A Report from Retail Commission on Shopper marketing (2010). Retrieved October 29, 2015, http://ecr-all.org/files/RetailCommission_executivereport-2010.pdf.

Shopping Marketing Best Practices. (2010).

Silveira, P., \& Marreiros, K. (2014). Shopper Marketing: A Literature Review. International Review of Management and Marketing, 4(1), 90-97.

Sorensen, H. (2009). The in-store audience. Journal of Advertising Research, 49(2), 176-179. doi:10.2501/S0021849909090242

Stahlberg, M., \& Ville, M. (2012). Shopper Marketing. 2nd Edition. London, UK: Kogan Page.

Stojanovic, Z., Filipovic, J., \& Stojkovic, D. (2014). Markets of Food with Nutritive and Health Claim: Producers and Retailers Perspectives. Economic Horizons, 16(1), 63-75. doi:10.5937/ekonhor1401063S

Verhoef, P. A., Neslin, S. A., \& Vroomen, B. (2007). Multichannel customer management: Understanding the researchshopper phenomenon. International Journal of Research in Marketing, 24(2),129-148. doi: 10.1016/j.ijresmar.2006.11.002.

Wyner, G. (2011). Shopper Marketing. Journal of Marketing Management, 20(1), 44-47. 
Received on $4^{\text {th }}$ December 2015,

after revision,

accepted for publication on $14^{\text {th }}$ April 2016.

Published online on $25^{\text {th }}$ April 2016.

Zoran Bogetic is an Associate Professor at the Faculty of Economics, University of Belgrade, The Republic of Serbia, where he teaches the following courses: Marketing Channels, Trade Management, Trade Marketing and Sales Management, and Supply Chain Management. His current research and consulting concerns involve the fields of marketing channels management, category management, supply chain management, efficient consumer response strategies, customer relationship management, and shopper marketing.

Djordje Kalicanin is an Associate Professor at the Faculty of Economics, University of Belgrade, The Republic of Serbia, where he acquired his vocation. He teaches the course of Strategic Management at the undergraduate level studies, as well as the courses in Managerial Decision Making, Strategic Finance and Business Strategy at the master's academic studies. His special research interests are enterprise value management, strategic planning and strategic implementation techniques, and performance measurement systems.

Dragan Stojkovic is an Assistant Professor at the Faculty of Economics, University of Belgrade, The Republic of Serbia. He teaches the following courses: Marketing Channels, Trade Marketing and Sales Management, Trade Management, Marketing Channels Strategies, and E-commerce and E-business. His research focus includes the following: the multi-channel strategy, retail marketing and management, e-commerce, and Internet marketing. He has published a significant number of international and domestic scientific papers. 


\title{
KUPOVNI MARKETING: NOVA PARTNERSKA PERSPEKTIVA U KANALIMA MARKETINGA
}

\author{
Zoran Bogetić, Đorđe Kaličanin i Dragan Stojković* \\ Ekonomski fakultet Univerziteta u Beogradu
}

\begin{abstract}
Kupovni marketing je obećavajuća poslovna inicijativa novijeg datuma. Dinstinkcija u odnosu na tradicionalni marketing trasira polje novog povezivanja, partnerstva i boljih rezultata maloprodavaca i dobavljača. U radu je razjašnjena nova perspektiva marketinga, sa kupcem u fokusu. Maloprodaja je identifikovana kao gravitaciono težište saradnje preduzeća i novog poslovnog konsenzusa. Razjašnjene su koristi i izazovi kupovnog marketinga, uključujući trasiranje efikasnijeg modela menadžmenta kategorije i partnerskog stvaranja vrednosti. Na tragu razvoja novih odrednica menadžmenta kategorije, u radu je istaknut aspekt institucionalizacije saradnje na planu kupovnog marketinga, kao i budućnost višekanalne analize i zadovoljenja kupca.
\end{abstract}

Ključne reči: kupovni marketing, uvidi o kupcima, partnerstvo, menadžment kategorije

JEL Classification: M21, M31, L25, L81

\section{UVOD}

Partnerske poslovne prakse od početka 80 tih godina XX-og veka, dobijaju na značaju. Jačanje maloprodaje u kanalima marketinga, utemeljeno na prednostima tehnološke revolucije, odredilo je strategijsku promenu ponašanja dobavljačkih organizacija i njihovo prilagođavanje $\mathrm{u}$ pravcu poslovnog povezivanja i saradnje (Petković \& Bogetić, 2014). Time je trasirana nova energija pozicioniranja na mestu prodaje i respekt kupca i ukupnog iskustva kupovine (Bogetić i Petković, 2014). Početkom 2000-tih inovirana je koncepcija kupovnog marketinga, a time i „rastuće

* Korespondencija: D. Stojković, Ekonomski fakultet Univerziteta u Beogradu, Kamenička 6, 11000 Beograd, Republika Srbija; e- mail: dstojkovic@ekof.bg.ac.rs razumevanje da je maloprodaja centar gravitacije $\mathrm{u}$ marketingu“" (O'Leary, 2013).

Fleksibilnost dobavljačkih organizacija i prilagođavanje zahtevima maloprodaje, ispoljava se i na planu relativizacije tradicionalnog fokusa na potrošača i saradnje na kupovnom marketingu. Kupac, tradicionalna preokupacija maloprodaje, dobija na značaju, a mesto prodaje novi pravac valorizacije.

Afirmiše se respekt i kapitalizacija razlike potrošača i kupca i razlike $u$ razmišljanju i motivaciji osobe $u$ prodavnici i van nje (Kapferer, 2008, 145; Sorensen, 2009; Shankar, Inman, Mantala, Kelley \& Rizley, 2011; Pincott, 2012). Maloprodavac i dobavljač usklađeno koriste svoje ekspertize "veoma pozitivno" unapređujući rezultate (Hoyt \& Swift, 2014), što dovodi 
do ekspanzuje investicija $\mathrm{u}$ kupovni marketing. C. Angrisani (2015) iznosi nalaz da su u periodu 2012-2014. više nego duplirani izdaci za kupovni marketing, sa značajnim učešćem od 13,5\% u ukupnim marketinškim izdacima u 2014. godini.

Partnerski rad je suština kupovnog marketinga i kada je pristup usko viđen, na nivou aktivnosti podsticanja prodaje u prodajnom objektu (Hoyt, 2006; Stahlberg \& Ville, 2012).

Komplementarno korišćenje ekspertiza i razvoj temeljnih uvida o kupcima je ključni aspekt kupovnog marketinga prema uticajnom udruženju Retail Commision on Shopper marketing (Shopper marketing Best Practices, 2010). Neophodno je razumeti motive, stavove i ponašanje kupca, kao i alternative uticaja na njega (Shankar, 2011, 3).

Partnerstvo maloprodavca i dobavljača na obuhvatnoj brizi o kupcima čini srž koncepcije kupovnog marketinga (Silveira \& Marreiros, 2014). Zaokruženi pogled na kupca, pri tom, podrazumeva tretman u svim kanalima, medijima i svim sredstvima, na nivou više kategorija proizvoda (Shankar et al, 2011).

Savremeni odnos kupaca prema maloprodajnoj ponudi sve je značajnije baziran na informacijama (Verhoef, Neslin \& Vroomen, 2007). Mnoge od tih informacija generišu se van prodajnih objekata, što dobija na značaju sa razvojem personalnih mobilnih uređaja (Shankar \& Balasubramanian, 2009; Shankar, Alladi, Hofacker \& Naik, 2010). Važan je, pri tom, balans aktivnosti kupovnog marketinga $u$ radnji i van nje (Wyner, 2011; Pincott, 2012), jer kupci očekuju ispunjenje obećanja (Interbrand, 2015) Otuda suštinu kupovnog marketinga treba da predstavlja integrisan marketing nastup (Fam, Merrilees, Richard, Joysa, Li \& Krisjanous, 2011).

Važnost teme kupovnog marketinga je višestruka. $\mathrm{S}$ jedne strane, $\mathrm{u}$ pitanju je perspektivna poslovna strategija i taktika za postizanje boljeg iskustva kupovine i razvoj lojalnosti kupaca, i unapređenje poslovnih rezultata. $S$ druge strane, u pitanju je novi pristup saradnji u kanalima marketinga, sa kupcem $u$ fokusu, koji nosi izazov približavanja i harmonizacije često različitih perspektiva razvoja efikasnih programa kupovnog marketinga.
Cilj ovog istraživanja je upravo sagledavanje pristupa usklađivanju interesa i delovanja maloprodavaca i dobavljača na planu kupovnog marketinga, od obostranog interesa. Usklađeno, partnersko delovanje, u krajnjoj liniji treba da bude efektuirano boljom uslugom kupaca i poslovnim rezultatima.

Akcentovanjem poslovnog značaja kupca kao centralne tačke tržišnog nastupa maloprodavaca i dobavljača, kupovni marketing nameće zahtev dodatnog razvoja i redefinisanja strategije i taktike menadžmenta kategorije proizvoda, uključujući novu metriku poslovnih aktivnosti i rezultata. Na tom planu cilj rada je, pored navedenog, da trasira novi strategijski okvir menadžmenta kategorije proizvoda i merenja rezultata, primereno filozofiji kupovnog marketinga.

Imajući u vidu važnost koncepcije kupovnog marketinga i definisane ciljeve istraživanja, u radu će biti testirana hipoteza:

H: Efektivan i efikasan kupovni marketing zasniva se na balansiranom partnerstvu maloprodavaca i dobavljača, a koje je podržano unapređenim menadžmentom kategorije proizvoda i prilagođenom metrikom performansi.

Briga o kupcu, u bilo koje vreme, i bilo gde, suština je zahteva poslovnog pristupa kupovnog marketinga (Gilbride, Inman \& Stilley, 2013). Tehnološki iskoraci i mogućnosti čine polazište novog, obuhvatnog modela marketinga fokusiranog na kupca (Egol, Sarma \& Sayani, 2013). Konceptualizacija marketinga usredsređenog na kupca, na planu partnerskog rada maloprodavaca i dobavljača, podrazumeva obuhvatno sagledavanje do sada realizovanih istraživanja i trasiranje novih smernica održivog pozicioniranja $\mathrm{u}$ kanalima marketinga.

U radu smo se opredelili za kvalitativnu metodologiju i prikupljanje podataka iz sekundarnih izvora shodno pitanju na koje treba dati odgovor (Marshall \& Rossman, 1995, 80-85; 99-107) i cilju holističkog razumevanja iskustva (Guglielmi, 2000, 45) kupovnog marketinga. Ovakvo opredeljenje vezano je i za činjenicu proučavanja nedovoljno proučenog, odnosno razvoj novih znanja i perspektiva (Goldberger, 1990; Buckler \& Zien, 1997). 
U radu je korišćem metod sinteze, koji je ima za cilj sintetizaciju postojećih teoretskih i praktičnih znanja o kupovnom marketingu, što „omogućava razumjevanje manifestovane pojave u kontekstu cijeline" (Mesihović, 2003, 69). Imajući u vidu da je u ovom radu u centru pažnje kupac i koncepcija kupovnog marketinga, neophodno je respektovati i humanističku stranu proučavanja, što je prema A. Mucchielli-u $(1996,60)$ karakteristika kvalitativnih istraživačkih metoda. Pomenimo da je istraživanje utemeljeno na nalazima teorije i prakse kupovnog marketinga zapadnih ekonomija, jer domaća evidencija ne postoji, što je i ujedno ključno ograničenje istraživanja.

Rad je, nakon uvodnih razjašnjenja, strukturisan u tri celine. Na početku, razmatramo elemente partnerske harmonizacije odnosa i interesa maloprodavaca, dobavljača i kupaca, na platformi kupovnog marketinga Nakon toga, polazeći od opredeljanja da je kupac preokupacija marketinške aktivnosti, proučavamo noseće elemente perspektivnog poslovnog procesa menadžmenta kategorije proizvoda. Ovde je težište na bržem i efikasnijem poslovnom procesu. Efikasan kupovni marketing podrazumeva praćenje ostvarenja ciljeva (interesa) partnera $\mathrm{u}$ ovom procesu. $\mathrm{U}$ tu svrhu neophodno je konstruisati i obuhvatan model merenja performansi. Tom izazovu je posvećena posebna tačka ovog rada. Pored toga u radu ćemo ukazati na institucionalne i višekanalne momente prakse kupovnog marketinga. Na kraju rada ćemo izneti ključne nalaze realizovanog istraživanja i stav o definisanoj istraživačkoj hipotezi. Pored toga, na osnovama aktuelnih dometa i sagledanih perspektiva, biće najavljena polja budućih istraživanja kupovnog marketinga, uključujući osvrt na interese domaćih maloprodavac, dobavljača i kupaca.

\section{BALANSIRANOST INTERESA KAO PRINCIP KUPOVNOG MARKETINGA}

Održivi kupovni marketing afirmiše pristup „sve tri strane na dobitku“. Samo u situaciji postizanja rezultata sa kojima su zadovoljni kako kupac, tako i maloprodavac i dobavljač, može se očekivati kontinuitet i razvoj prakse kupovnog marketinga. Balansiranost interesa zainteresovanih strana tako postaje ključni princip koncepcije kupovnog marketinga.
Usklađivanje potreba i preferencija maloprodavca i dobavljača sa najboljim rešenjem za kupca čini okosnicu partnerstva u kupovnom marketingu. Polazište saradnje je razvoj kvalitetnih uvida o kupcima i razumevanja šta su dugoročni interesi sve tri strane. Partneri razvijaju usklađene planove akcija kupovnog marketinga na nivou prodajnog objekta, nakon čega sledi operacionalizacija dogovorenog na mestu prodaje.

Mogući različiti interesi, kao i perspektiva „zadovoljne sve tri strane" ilustrovane su Tabelom 1.

Tabela 1 upućuje na zaključak o moguće veoma različitim viđenjima kupovnog marketinga od strane maloprodavca, dobavljača i kupca, sa ishodom mogućih konflikata i problema. Tako, na primer, kada dobavljač forsirajući svoj brend razvija akcije unapređenja prodaje bez uvida kakve efekte postiže na planu prodaje „ostale“ ponude prodajnog objekta, moguća je realna šteta koju trpi maloprodavac. Moguće je, na primer, da pomaci u plasmanu jednog artikla znače jednostavnu supstituciju prodaje drugog proizvoda, bez pomaka u ukupnoj potrošnji ili čak na štetu ukupnog rezultata prodajnog objekta.

Na drugoj strani, apsolutna favorizacija proizvoda privatne robne marke može doneti probleme maloprodavcu. Kupci koji su, naime, orijentisani ka brendiranim proizvodima, po pravilu bojkotuju ponude koje pretenduju da naglo supstituišu etablirane brendove, što znači potencijalno nezadovoljstvo neodmerenom ponudom proizvoda privatne robne marke. Otuda i zaključak o dugoročnom problemu nesaglasja maloprodavca i dobavljača (Stojanovic, Filipovic \& Stojkovic, 2014).

Kupac iznad svega želi da podmiri svoje potrebe na efikasan način, sa dobrim iskustvom kupovine, koje namerava da ponovi. Nesaglasje maloprodavca i dobavljača kupcu može doneti kratkoročne koristi, sa izvesnim razočaranjem očekivanja koja je razvio. Neodržive ponude na maloprodajnom mestu ne donose dugoročnu satisfakciju i lojalnost kupca.

Kupovni marketing je poslovni proces koji u svojoj suštini uvida o kupcima podrazumeva jedinstven poslovni proces maloprodavca i proizvođača. Informacije i ekspertize maloprodavca i proizvođača 
Tabela 1 Različite perspektive kupovnog marketinga

\begin{tabular}{|c|c|c|c|c|}
\hline \multicolumn{5}{|c|}{ Perspektiva } \\
\hline Područje & Maloprodavac & Dobavljač & Kupac & Zadovoljne sve tri strane \\
\hline $\begin{array}{l}\text { Pogled na } \\
\text { ponudu }\end{array}$ & $\begin{array}{l}\text { Treba postići profit na } \\
\text { nivou kategorije. } \\
\text { Prioritetni tretman } \\
\text { privatne robne marke. } \\
\text { Sinergija portfolija } \\
\text { kategorija, razvoj i } \\
\text { ekspolatacija. }\end{array}$ & $\begin{array}{l}\text { Fokus na sopstveni } \\
\text { brend i komunikacija } \\
\text { u brojnim tačkama } \\
\text { kontakata. } \\
\text { Pravovremena } \\
\text { višekanalna brend } \\
\text { komunikacija. }\end{array}$ & $\begin{array}{l}\text { U svim kontaktima } \\
\text { pravovremene i } \\
\text { precizne informacije } \\
\text { o široj ponudi i } \\
\text { proizvodima. } \\
\text { Efikasnija pretraga, } \\
\text { upoređivanje i } \\
\text { informisanje o akcijama } \\
\text { unapređivanja prodaje. }\end{array}$ & $\begin{array}{l}\text { Razvoj rešenja (proizvodi i/ } \\
\text { ili usluge od proizvođača i } \\
\text { maloprodavca) koje najbolje } \\
\text { odgovara potrebama i } \\
\text { preferencijama kupca i } \\
\text { komunikacija putem kanala, u } \\
\text { raznim tačkama kontakata. }\end{array}$ \\
\hline Raspoloživost & $\begin{array}{l}\text { Upravljanje izlaganjem } \\
\text { kategorije na polici. } \\
\text { Postavka rafova koja } \\
\text { doprinosi većoj poseti, } \\
\text { prodaji i profitima. } \\
\text { I višekanalna prodaja. }\end{array}$ & $\begin{array}{l}\text { Dominantno prisustvo } \\
\text { na rafovima, sa } \\
\text { najboljim pozicijama za } \\
\text { sopstvene brendove. } \\
\text { Široka pokrivenost } \\
\text { kanala i dostupnost } \\
\text { proizvoda. }\end{array}$ & $\begin{array}{l}\text { Pravi proizvodi na } \\
\text { pravom mestu, u pravo } \\
\text { vreme. } \\
\text { Efikasna kupovina. } \\
\text { Lako plaćanje i brza } \\
\text { isporuka. }\end{array}$ & $\begin{array}{l}\text { Pravovremena dostupnost } \\
\text { proizvoda u svim kanalima } \\
\text { marketinga. } \\
\text { Efikasna dostupnost i isporuka } \\
\text { ciljanih i komplementarnih } \\
\text { proizvoda putem svih kanala. }\end{array}$ \\
\hline $\begin{array}{l}\text { Unapređenje } \\
\text { prodaje }\end{array}$ & $\begin{array}{l}\text { Balansirano } \\
\text { kombinovanje akcijskih } \\
\text { ponuda brendova i } \\
\text { proizvoda u kategoriji. } \\
\text { Upravljanje } \\
\text { profitabilnošću } \\
\text { korišćenjem ponuđenih } \\
\text { rešenja unapređenja } \\
\text { prodaje od strane } \\
\text { proizvođača. }\end{array}$ & $\begin{array}{l}\text { Promišljeni podsticaji } \\
\text { za kvalitetnije tržišno } \\
\text { učešće sopstvenih } \\
\text { brendova. } \\
\text { Usklađenost akcija } \\
\text { unapređenja prodaje sa } \\
\text { strateškim, operativnim } \\
\text { i konkretnim ciljevima } \\
\text { vezanim za brend. }\end{array}$ & $\begin{array}{l}\text { Dobre ponude za } \\
\text { najpoželjnije brendove/ } \\
\text { proizvode. } \\
\text { Odgovarajuća ili } \\
\text { najpoželjnija vrsta } \\
\text { podsticaja, uključujući } \\
\text { one zasnovane na ceni. } \\
\text { Dobro informisanje o } \\
\text { cenovnim podsticajima. }\end{array}$ & $\begin{array}{l}\text { Balansirane, pravovremene } \\
\text { akcije unapređenja prodaje } \\
\text { - pravi brendovi, na pravom } \\
\text { mestu, u pravo vreme. }\end{array}$ \\
\hline $\begin{array}{l}\text { Dodatne pozicije } \\
\text { izlaganja }\end{array}$ & $\begin{array}{l}\text { Dobro promišljen } \\
\text { menadžment dodatnih } \\
\text { pozicija tokom godine. } \\
\text { Dodatne pozicije za } \\
\text { sopstvenu ili privatnu } \\
\text { robnu marku. }\end{array}$ & $\begin{array}{l}\text { Dodatno isticanje } \\
\text { sopstvenih brendova. } \\
\text { Efektivni detalji } \\
\text { usklađeni sa strateškim } \\
\text { ciljevima na nivou } \\
\text { brenda podstiču } \\
\text { kupovinu. }\end{array}$ & $\begin{array}{l}\text { Podsećanje, } \\
\text { informisanje, } \\
\text { predstavljanje } \\
\text { brendova/proizvoda na } \\
\text { lak i atraktivan način. }\end{array}$ & $\begin{array}{l}\text { „Prava“ vrsta dodatnih } \\
\text { pozicija u „pravim“ prolazima } \\
\text { za „pravi“ brend koji odgovara } \\
\text { potrebama ciljanih kupaca. }\end{array}$ \\
\hline
\end{tabular}

Izvor: Shankar, 2011, 28-29

iziskuju da budu objedinjene da bi slika o kupcima bila celokupna. Separatni interesi i akcije podsticanja prodaje kupovnim marketingom često dovode do kontradiktornih poslovnih efekata na duži rok. Otuda i kompleksnost formulacije balansiranih mera kupovnog marketinga, bez čega i nema jasne slike šta se zapravo postiže pojedinačnim akcijama aktiviranja prodaje u prodavnici.

Sistematizujući nalaze vodećih autoriteta $\mathrm{u}$ oblasti kupovnog marketinga, P Silveira i K. Marreiros (2014) daju pregledno razgraničenje očekivanih koristi od kupovnog marketinga kao inovativne poslovne prakse: 
- Kupac - Potencijalne koristi od kupovnog marketinga: proizvodi, usluge, iskustva kupovine i komunikacije prilagođeni su kupcu. Relevantnost i prihvatljivost.

- Maloprodavac - Potencijalne koristi od kupovnog marketinga: Unapređena satisfakcija kupca, pored bolje prodaje i diferenciranja, dovodi do veće lojalnosti i preporučivanja. Efikasniji menadžment kategorije (asortimana), prodajnog prostora i odnosa sa dobavljačima.

- Dobavljač - Potencijalne koristi od kupovnog marketinga: jačanje vrednosti brenda; efektivnija aktivacija brenda $\mathrm{u}$ trenutku kupovine; identifikacija ključnih dodirnih tačaka i stimulansa za efektivniju interakciju sa kupcem; rast lojalnosti i prodaje; dublji odnos sa maloprodavcem.

Pregled mogućih koristi od kupovnog marketinga upućuje na zaključak o misiji poslovne strategije kojom se stabilizuju odnosi u kanalima marketinga, odnosno, postiže konsenzus maloprodavaca i dobavljača da je interes kupca prioritetni cilj međusobne saradnje i povezivanja. Unapređenje iskustva kupovine kupca prodajnog objekta, na bazi dobrog poznavanja interesa i ponašanja, maloprodavcima i dobavljačima donosi bolje prodajne rezultate, uz postizanje ciljeva strategijskog pozicioniranja njihovih brendova, na temeljima bliže i posvećenije saradnje. Treba uočiti da je kupovni marketing posebno važan interes dobavljačkih organizacija, jer se ovom strategijom približavaju maloprodavcima, razvijajući dublji odnos i sigurniju saradnju.

Izazov kupovnog marketinga je promena poslovnog fokusa sa potrošača na kupca i razvoj adekvatnih znanja i veština primerenih novoj poslovnoj strategiji. Pretpostavka kupovnog marketinga je promena poslovne kulture u kompanijama, sa organizacionim i proceduralnim rešenjima koja omogućavaju realizaciju novog pristupa. Tradicionalni pristup marketingu u maloprodajnim i dobavljačkim organizacijama po inerciji predstavlja „prepreku“ brzog prihvatanja i realizacije kupovnog marketinga, uključujući izazov razvoja novih znanja, planova i terenskog rada, $u$ funkciji kupca i boljeg iskustva kupovine.
Sistematizovan pregled potencijalnih problema $\mathrm{u}$ implementaciji koncepcije kupovnog marketinga sadrži sledeće elemente (Silveira \& Marreiros, 2014):

- nedostatak informacija i istraživanja o ponašanju kupaca, uz kompleksnost razumevanja kupaca i otežanu predvidljivost;

- tehnički problemi i troškovi strukturisanja uvida o kupcima za različite maloprodajne formate;

- otežana promena fokusa sa potrošača na kupca i pravljenje ponuda i poruka koje nisu relevantne za kupca;

- nedostatak kvalifikovanih menadžera za kupovni marketing;

- nedostatak mera kupovnog marketinga i tradicionalno vrednovanje aktivnosti kupovnog marketinga;

- tradicionalni procesi komunikacije, alokacije sredstava i organizacione strukture, utemeljeni na pretpostavkama;

- problemi usklađivanja maloprodavaca i dobavljača na planu strategije i taktike i rešenja od koristi za sve tri strane;

- dobavljači usredsređeni na kratkoročna rešenja i prodaju proizvoda.

Da bi kupovni marketing imao dobru osnovu $\mathrm{u}$ maloprodajnim i dobavljačkim organizacijama, treba otkloniti eventuelne nedostatake tradicionalnog poslovanja. Promena fokusa sa potrošača na kupca podrazumeva nova znanja i veštine, sa adekvatnim merama rezultata. Maloprodavac i dobavljač treba da formiraju zajedničke uvide o kupcima, na kojima temelje partnerski razvijene ciljeve, planove i procedure operacionalizacije zadataka razvoja odnosa sa kupcima. Sastavni deo novog poslovnog procesa je i razvoj novih planova i aktivnosti supervizije rada, sa elementima kontinuiranog unapređivanja rada i rezultata. 


\section{PARTNERSTVO NA MENADŽMENTU KATEGORIJE FOKUSIRANOM NA KUPCA}

Poslovni proces kupovnog marketinga može da bude sastavni deo menadžmenta kategorije proizvoda (Bogetić, 2007), odnosno, aktivnog pristupa plasmanu konkretnog brenda, konkretnog dobavljača prodajnog objekta. Podsticanje prodaje brenda u sklopu aktivnosti kupovnog marketinga tako predstavlja deo širih promotivnih aktivnosti asortimana $u$ prodajnom objektu. Plan unapređenja prodaje asortimana kategorije tako može da bude sazdan od niza parcijalnih planova kupovnog marketinga na nivou pojedinih artikala, odnosno, brendova. Rezultat su balansirane akcijske prodaje u prodajnom objektu, vodeći računa o postizanju definisanih poslovnih ciljeva na nivou artikla, kategorije $i$ prodavnice $u$ celini.

Poslovni proces menadžmenta kategorije fokusiran na kupca ima svoje specifičnosti i određujuće momente, koji ga potencijalno čine kraćim, bržim i efektivnijim. Uvidi o kupcima su okosnica formulacije

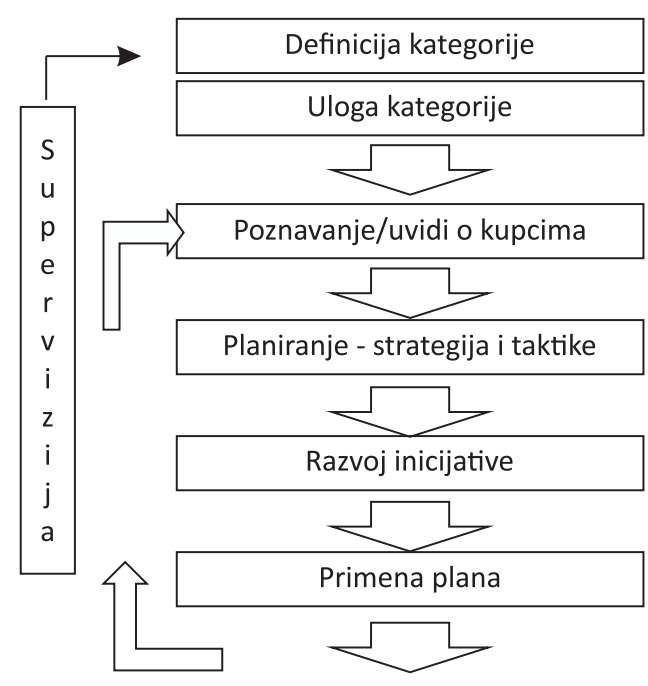

Slika 1 Poslovni proces menadžmenta kategorije fokusiran na kupca

Izvor: Fowler \& Goh, 2012, 104 i unapređivanja poslovnog procesa menadžmenta kategorije, u cilju efikasne i održive prodaje asortimana kategorije, u celini i na nivou pojedinih brendova.

$\mathrm{Na}$ početku poslovnog procesa menadžmenta kategorije (Slika 1), kupovni marketing treba da odgovori na pitanje da li je sadržaj kategorije jasan i funkcionalan sa stanovišta profila kupaca, potreba koje se podmiruju i profila prodajnog objekta. Maloprodavac treba da definiše kategoriju u skladu sa ciljnim kupcima i zahtevom kupovne misije koja se realizuje $u$ prodajnom objektu, $u z$ imperativ efikasnosti asortimana i promotivnih aktivnosti u konkretnoj situaciji. Dobavljač, na drugoj strani, konkretnoj prodajnoj situaciji prilagođava ponudu, primarno razvijajući adekvatan marketing miks za aktivnu prodaju u prodavnici.

Polazište kupovnog marketinga na mestu prodaje je razjašnjenje profila kupaca prodajnog objekta i njihovog ponašanja u procesu kupovine. Pitanja ko su najaktivniji kupci u prodajnom objektu, koje potrebe podmiruju, šta je zahtevani maloprodajni servis i šta su neiskorišćene poslovne šanse, predstavljaju polazište maloprodajne analize na nivou svake kategorije proizvoda. Maloprodavac kupovnim marketingom unapređuje kako rezultate prodajnog objekta i konkretne kategorije, tako i rezultate pojedinačnog proizvoda za koji se osmišljava i realizuje poslovni plan. Poznavanje ciljnih kupaca, traženih proizvoda i kategorija, maloprodavcima pruža vredan pregovarački autoritet $\mathrm{u}$ odnosu sa perspektivnim dobavljačima. Time se unapređuju odnosi sa dobavljačima, ali i asortiman kategorije (Silveira \& Marreiros, 2014).

Kupovni marketing dobavljačima, na drugoj strani, donosi fokus na maloprodavce i prodajne objekte koji su najvažniji za ciljane kupce, sa određenom potrebom, $u$ različitim situacijama. Dobavljač $u$ ovoj situaciji razaznaje ključne dodirne tačke sa kupcima i definiše efikasne komunikacione kanale. Rezultat je formulisan akcioni plan za aktiviranje kupaca, $\mathrm{u}$ funkciji lakše kupovine i njenog ponavljanja. Ponuda je time efikasnija, kao i upravljanje prodajnim prostorom.

Zaokružen model poslovnog procesa menadžmenta kategorije fokusiranog na kupca definisan je $u$ 
sedam koraka i usmeren je na kupca (Slika 1). Model podrazumeva: definiciju kategorije, ulogu kategorije, uvide o kupcima, strategijski i taktički plan, primenu plana i praćenje i korekcije implementacije strategije menadžmenta kategorije. Ključni momenat ovog poslovnog procesa je aktivno korišćenje uvida o kupcima koji su prikupljeni programima lojalnosti ili nekim drugim pristupom menadžmenta odnosa sa kupcima (CRM - Customer Relationship Management), da bi servis bio efikasan i efektivan (Marinkovic \& Senic, 2012).

U koracima poslovnog procesa definicije i određivanja uloge kategorije fokus je na značajnijoj usklađenosti sa maloprodajnom strategijom i ključnim (odredišnim) kategorijama. Kada je završeno definisanje kategorije i njene uloge, taj posao se samo izuzetno revidira, ubrzavajući tako proces inoviranja i prilagođavanja operativnog poslovanja na nivou kategorije. Dva koraka poslovnog procesa menadžmenta kategorije tako su „završena“, dok operativni rad na plasmanu asortimana kategorije kontinuirano teče.

Centralni deo inoviranog poslovnog procesa uključuje: superviziju ili kontrolu i razvoj; generisanje uvida o kupcima; strategijsko planiranje; taktičko planiranje; inicijative sa dobavljačima; primenu plana; kontinuitet supervizije menadžmenta kategorije. Fokus je na brzom korišćenju šansi vezanih za kategoriju, na nivou ponašanja kupaca i njihove satisfakcije.

Generisanje uvida o kupcima podrazumeva odgovore na pitanja o maloprodajnom okruženju, uključujući: potrošače i kupce; proizvode i usluge; maloprodavce i konkurente; lojalnost kupaca; maloprodajno tržište u celini. Cilj je temeljno sagledavanje ponašanja kupaca i uključivanje znanja o kupcima u poslovni proces menadžmenta kategorije, sa efektom asortimana i prezentacije kategorije proizvoda primerenih prodavnici i pripadajućim modalitetima kupovina. Tako, na primer, često je neophodno unaprediti strukturu i količinu ponuđenog asortimana kategorije, jer pretrpanost robom nepotrebno frustrira kupce, koji imaju jasne razloge posete prodavnice. Pretpostavka dobrih odluka o asortimanu i drugim elementima ponude $\mathrm{u}$ prodajnom objektu su objektivizovane informacije o kupcima.
Akcentovanjem fokusa na kupca, istovremeno, treba postići strategijsko i lokalno pozicioniranje maloprodavca na nivou kategorije. Maloprodavac treba da ima razvijenu ponudu primerenu konkretnom kupcu prodavnice, istovremeno postižući i šire kompanijske ciljeve.

Dinamičnost i atraktivnost ponude asortimana kategorije $u$ prodavnici postiže se tako što maloprodavac pojedine segmente asortimana različito tretira, definišući različite, a opet kompatibilne ciljeve koje želi da postigne. Tako jedan deo asortimana kategorije može privlačiti kupce $u$ prodajni objekat generišući saobraćaj, dok drugi deo asortimana kategorije može biti razvijen tako da generiše gotovinu. Pored navedenog, maloprodavac sa asortimanom može postizati sledeće ciljeve: kreiranje uzbuđenja u prodajnom objektu; unapređenje cenovnog imidža; generisanje profita; unapređenje vrednosti transakcija; zaštita od konkurencije; unapređenje imidža izabranog prodajnog objekta (Bogetić, 2007, 148). Inovativni ciljevi koje treba postići na nivou kategorije, pored navedenog, uključuju (Fowler \& Goh, 2012, 104-105): lakoću kupovina u okviru kategorije (pristup lake komunikacije); kupovinu većih količina ili pakovanja (transakcioni pristup i korišćenje unakrsnog izlaganja robe u okviru kategorije); entuzijazam kupaca (pristup kupcima koji su lojalni i nisu vođeni cenom); prilika za kupovinu (degustacioni pristup); i razvoj novih kupaca brenda (fokus na odabrane segmente kupaca). Izloženi aspekti potencijalnih uloga delova asortimana kategorije upućuju na zaključak da postoje velike mogućnosti kreativnog kombinovanja i diferenciranja ukupne ponude.

Nakon definisanja strategijskog i taktičkog plana kategorije, maloprodavac razvija široku partnersku inicijativu, koja je preduslov realizacije poslovnog plana. Diferenciranje i konkurentska prednost na nivou kategorije zahteva kvalitetnog partnera, sa adekvatnim kapacitetima. Maloprodavcu preostaje temeljna analiza raspoloživih alternativa nabavke i definisanje prioriteta. Radeći na tome, maloprodavac bira dobavljače sa kojima ce realizovati balansirane programe kupovnog marketinga na nivou odabranih kategorija proizvoda, respektujući cilj unapređenja poslovnog rezultata, mereno na nivou kategorije i prodajnog objekta u celini (Shankar \& Bolton, 2004). 
Plan primene programa menadžmenta kategorije treba da bude detaljan, kako na nivou portfolia akcija unapređenja prodaje, tako i konkretizacijom saradnje sa odabranim dobavljačima. Usaglašenost partnera o svim elementima poslovnog plana se podrazumeva, omogućavajući harmoničnu operacionalizaciju zadataka i postizanje dobrih, usklađenih rezultata. Primena poslovnog plana razvijenog za kategoriju proizvoda u značajnoj meri se oslanja na kontinuirani proces nadgledanja ili supervizije, što omogućava korekcije $\mathrm{i}$ "u hodu“ poslova unapređenja menadžmenta kategorije. Time se dodatno unapređuje efikasnost i efektivnost menadžmenta kategorije, uz brži i bolji servis za kupca.

Kupovni marketing se razlikuje po kategorijama, što određuje njihova priroda, odnosno, profil tražnje i modeli kupovina koji se manifestuju. Dobru ilustraciju dinamičnosti kupovnog marketinga od kategorije do kategorije proizvoda predstavlja razlika trajnih i netrajnih potrošnih dobara, i razlika relevantnih praksi kupovnog marketinga. S tim u vezi, potrebno je sagledati verovatnoću planirane, odnosno, neplanirane kupovine, shodno prirodi navedenih kategorija i profilu njihovih kupaca (Inman, Winer \& Ferraro, 2009).

U odnosu na netrajna potrošna dobra, trajna potrošna dobra imaju duži ciklus eksploatacije proizvoda i mnoga podrazumevaju duži proces traženja, pa je samim tim njihov ciklus kupovine duži. Nadalje, liste za kupovinu većine netrajnih potrošnih dobara načelnog su karaktera i sadrže nazive kategorija (na primer, meso, mleko, deterdžent, slatkiši), uz relativno zanemarivanje naziva brendova i prisutnu supstitabilnost, pa je otuda važan cilj proizvođača da njihovi brendovi „dođu“ na listu za kupovinu.

Prisustvo na listi za kupovinu je od prioritetnog značaja za proizvođače trajnih potrošnih dobara, gde je tražnja u značajnoj meri definisana brendovima, pa je za dobavljača od prioritetnog značaja da njegov brend bude na listi za kupovinu koju „nosi“ kupac. Društvene mreže i društveni mediji imaju značajniju ulogu u ciklusu kupovine takve i druge robe sa dužim rokom trajanja. Komunikacija "od usta do usta“ i prenošenje iskustava sa brendom značajno utiču na reputaciju i tražnju za brendom. Ovom aspektu tražnje za brendom, kupovni marketing poklanja posebnu pažnju.

Taktike kupovnog marketinga primerene različitim kategorijama proizvoda se razlikuju u meri u kojoj se razlikuje priroda kupovina i ponašanje kupaca. Tako maloprodavci trajnih potrošnih dobara često koriste shop-in-shop rešenja da bi diferencirali ponudu, olakšali snalaženje kupaca i podstakli kupovine. $\mathrm{Na}$ tom planu posebno su aktivne robne kuće, tražeći prostor za inoviranje poslovanja i opstanak u sve žešćoj konkurenciji. Primer je transformacija prodajnog prostora robnih kuća JCPenney u kolekciju shop-inshop radnji (Bhasin, 2012). Pored shop-in-shop koncepta, maloprodavci trajnih potrošnih dobara, zbog složenog procesa odlučivanja kupaca prilikom kupovine, u naporu produžetka trajanja posete i povećanja verovatnoće kupovine, često olakšavaju boravak na mestu prodaje tako što „zbrinjavaju“ decu kupaca, nude prostor za pauzu uz kafu, i slično.

\section{PRAĆENJE PERFORMANSI ZAJEDNIČKOG RADA NA KUPOVNOM MARKETINGU}

Kupovni marketing zahteva dublju saradnju između dobavljača i maloprodavaca, nego što je to bilo $u$ tradicionalnom marketingu. Polja delovanja se prostiru na više funkcija, odnosno, više procesa, čime se proširuje i produbljuje horizont praćenja efekata tog novog pristupa marketingu. Da bi se pratili efekti kupovnog marketinga, neophodno je najpre postaviti zajedničke ciljeve, a zatim i merila ostvarenja tih ciljeva. U tu svrhu, predlažu se liste rezultata (scorecards), koje na obuhvatan način govore o ostvarenju rezultata kupovnog marketinga iz ugla preduzeća (Corporate Shopper Marketing Scorecards), iz ugla kategorije proizvoda maloprodavca (Category Scorecard) i ugla dobavljača (Account Scorecard) (GMA \& Deloitte, 2008). Lista rezultata kupovnog marketinga na nivou preduzeća prati progres u implementaciji ove strategije, pri čemu ona sumira ključne pokazatelje na nivou kategorije i na nivou dobavljača. Menadžeri kategorija koriste listu rezultata na nivou kategorije da bi dobili uvid u to na koji način kupovni marketing doprinosi rezultatima kategorije proizvoda. 
Dobavljači koriste svoju listu rezultata kupovnog marketinga da bi pratili efekte kupovnog marketinga na ostvarenje ciljeva $\mathrm{u}$ odnosu na maloprodavce, kao i da bi pratili zadovoljstvo (ostvarenje interesa) partnera maloprodavca. Ovu listu, dobavljači treba da inkorporiraju u listu ciljeva definisanih u sopstvenoj strategiji marketinga i prodaje.

Bez obzira na čvrstu volju partnera u kupovnom marketingu, praksa merenja efekata ove strategije nije dala nedvosmisleni i do kraja zaokruženi skup merila. Štaviše, istraživanja pokazuju da i maloprodavci i dobavljači prepoznaju važnost ove prakse njihove saradnje, ali isto tako ističu da je efikasnost saradnje partnera u ovom pogledu niska (GMA \& Deloitte, 2008, 25). Lideri kupovnog marketinga, maloprodavci i dobavljači, su obično fokusirani na prodaju, profit, tržišno učešće (po kategorijama), broj kupaca (po segmentima), aktivnosti pre ulaska u radnju, broj poseta prodavnicama, potrošnju po poseti i broj kupljenih proizvoda u potrošačkoj korpi (KiE Square, 2015). Proizlazi da su mogućnosti za unapređenje metrike kupovnog marketinga velike, odnosno da je to polje koje je vrlo plodno za inovacije. U tom kontekstu predlažu se, između ostalog, sledeće metrike koje prate: pažnju i razmatranje kupaca u kupovini (blizina potrošača u odnosu na proizvod, vreme zadržavanja pažnje na proizvodu, dodirnuti/razgledani proizvodi); prirodu odluka (planirana versus neplanirana kupovina, učestala versus neučestala, hedonistička versus funkcionalna); i među-efekte (efekti kupovine jedne kategorije na kupovinu proizvoda druge kategorije). U tom smislu, koriste se i mogućnosti koje pružaju nove metodolgije koje uključuju biometriku (na primer, praćenje rada srca), kamere koje prate pokrete oka, tela i druga. Najveći su izazovi svakako $\mathrm{u}$ povezivanju metrike kupovnog marketinga sa vrednošću za vlasnike, odnosno, akcionare (Shankar et al, 2011).

Praksa merenja efekata kupovnog marketinga razvijala se kroz vreme, i vremenom su se nametnula neka od merila koja najpribližnije govore o ostvarenju ciljeva profitabilnosti partnera. Oduvek su postojali izazovi u praćenju efekata ulaganja u marketing, a takvi izazovi nisu izostali ni ovog puta. Ono što je izvesno jeste da programi kupovnog marketinga treba da doprinesu rastu prodaje brendiranih proizvoda dobavljača, satisfakciji kupaca, zajedno sa rastom prodaje i profita maloprodavaca. Međutim, izgradnja sistema merila $\mathrm{u}$ kupovnom marketingu ne treba da se fokusira samo na transakciju, već i na ponašanje kupaca, kao i na njihove stavove. Time se dobija na širem obuhvatu merenja kupovnog marketinga. Slikom 2 ilustrovani su polje merenja, ciljevi dobavljača i ciljevi maloprodavaca koji su u skladu sa prethodnim stavovima.

Slika 2 ukazuje na to da realizacija ciljeva kupovnog marketinga treba da ima pozitivne posledice na prinos na investirano (ROI - Return On /Marketing/ Investment), rast obima prodaje, povećanje produktivnosti, itd. Konačni cilj kupovnog marketinga je nedvosmislen. To je stvaranje vrednosti za kupce i stvaranje vrednosti za vlasnike maloprodajnih i dobavljačkih preduzeća.

Podizanje satisfakcije kupca u prodavnici doprinosi njegovoj percepciji dobijene vrednosti, čime se povećava njegova spremnost da plati višu cenu. Takođe, pozitivan stav kupca ubrzava njegovu odluku o kupovini, što dovodi ne samo do uvećanih, već i do ubrzanih odliva gotovine ka maloprodavcu, uz smanjenje rizika da će „propustiti“ kupovinu koja je planirana programom kupovnog marketinga, čime se, zapravo, povećava verovatnoća kupovine. Time se direktno utiče na maksimiranje stvorene vrednosti za maloprodavca. Uvećani i ubrzani tokovi gotovine prenose se na dobavljača brendiranih proizvoda, čime se direktno utiče na stvorenu vrednost i za ovog partnera $\mathrm{u}$ procesu kupovnog marketinga. Logika stvaranja vrednosti za kupce, maloprodavce i dobavljače brendiranih proizvoda prikazana je na Slici 3.

Na osnovu Modela partnerskog stvaranja vrednosti u kupovnom marketingu (Slika 3), može se zaključiti da je proces kupovnog marketinga snažan i kontrolabilan instrument stvaranja vrednosti za kupce i za vlasnike preduzeća involviranih u tom procesu. Razvijeni model partnerskog stvaranja vrednosti u kupovnom marketingu upućuje na zaključak o efektivnosti i održivosti poslovne koncepcije i na tim osnovama razvijene saradnje $\mathrm{u}$ kanalima marketinga. 


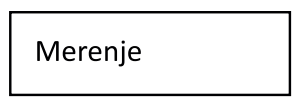

Podaci o transakciji kupca

\section{Podaci o} ponašanju kupca

$$
\text { Ciljevi dobavljača }
$$

Obim prodaje ili prihodi od prodaje + udeo u asortimanu, udeo u ukupnom trošenju na kategoriju, lojalnost brendu, program prinosa na investirano (ROI - Return On Investment)
Ciljevi maloprodavca

Rast prodaje u istoj prodavnici, prodaja uvezanih kategorija, veličina korpe i profit po kvadratnom metruprofit

\section{Učestalost obilazaka,} dubina ulazaka, penetracija kartica

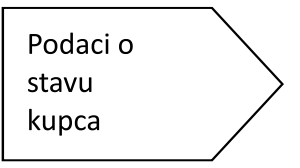

Uključenje u listu "za kupiti", razmatranje kupca, angažovanje kupca, ponašanje kupca kao „advokata“ brenda
Uključenje u listu

angažovanje kupca

ponašanje kupca

brenda lojalnosti l angažovanje

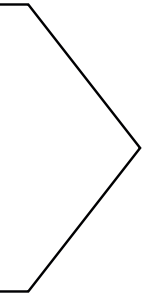

angažovanje

Slika 2 Obuhvatni program merenja kupovnog marketinga

Izvor: Khuller, 2013, 15

\section{INSTITUCIONALIZACIJA SARADNJE I BUDUĆNOST KUPOVNOG MARKETINGA}

Kupovni marketing u svojoj suštini predstavlja partnersku poslovnu inicijativu, što potvrđuje i svojevrsna institucionalizacija saradnje na razvoju koncepcije. Retail Commission on Shopper Marketing Initiative, na primer, predstavlja reprezentativnu ilustraciju strategijske alijanse vodećih marketinških institucija koja, od 2009. godine, radi na razvoju koncepcije kupovnog marketinga. Noseće organizacije uključene u ovu inicijativu su The Coca-Cola Company, In-Store Marketing Institute, i Partnering Group (Shopping Marketing Best Practices, 2010). Važnost institucionalne saradnje za kupovni marketing ilustruje i istraživačko-konsultantska aktivnost Food Marketing Institute/ FMI (The Voice of Food Retail) i Grocery Manufacturers Association/ GMA (The Association of Food, Beverage and Consumer Products Companies) (FMI, 2015; GMA \& Deloitte, 2015). FMI, na primer, u 2015. godini objedinjuje interese 1225 maloprodajnih i veleprodajnih kompanija širom sveta, na planu istraživanja i obrazovanja, uključujući analizu aktivnosti 40.000 maloprodajnih objekata i 25.000 farmaceutskih radnji. IELKA (The Institute of Retail Consumer Goods-GR) je, takođe, asocijacija koja u Grčkoj promoviše istitucionalnu saradnju 6 ključnih 


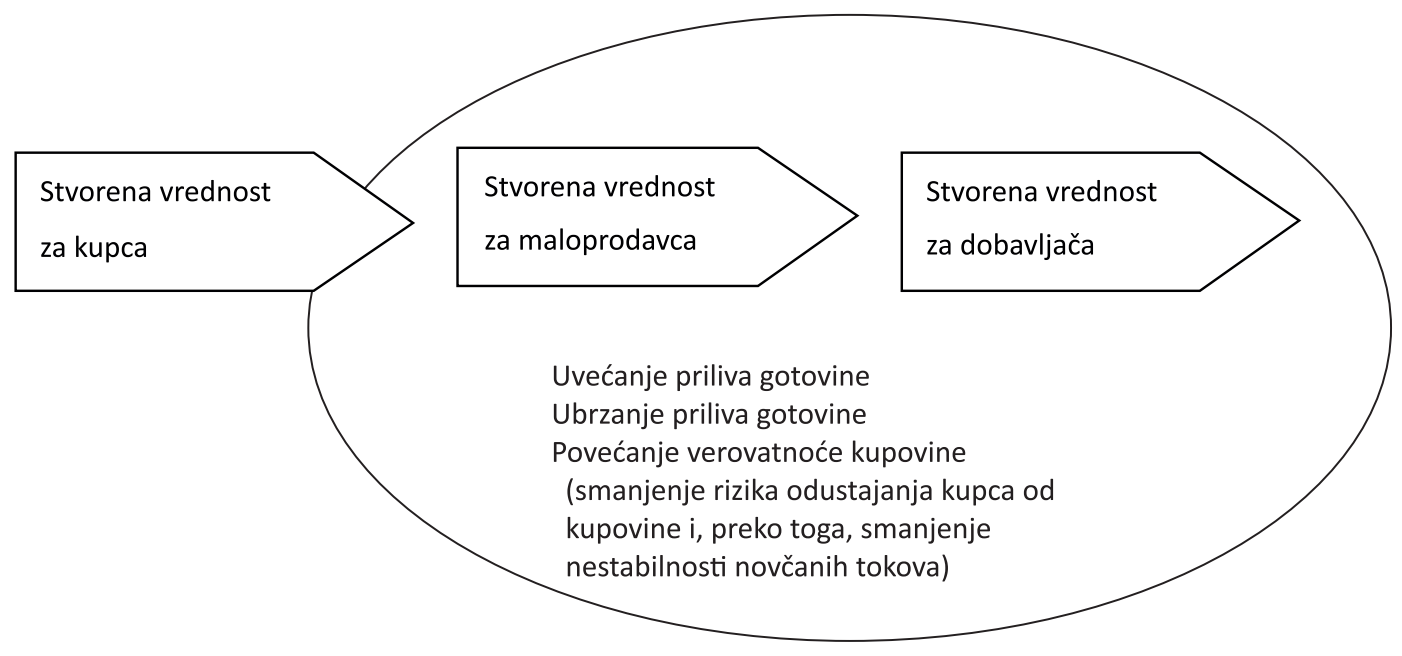

Slika 3 Model partnerskog stvaranja vrednosti u kupovnom marketingu

Izvor: Autori

maloprodajnih lanaca na planu istraživanja i afirmacije pozitivnih maloprodajnih praksi (IELKA, 2013).

Rastuća institucionalizacija saradnje na kupovnom marketingu vezana je i za širenje istraživačkog polja, vezanog ne samo za aspekte tradicionalno viđene konkurencije, nego i za sve aktivniju konkurenciju višekanalnog tipa. Rastuća umreženost savremenog kupca, koji koristi višestruke kanale informisanja i pretraživanja tokom ciklusa kupovine, kontinuirano otvara nova pitanja i mogućnosti kupovnog marketinga. Motivi, proces i okidači kupovine kupca u višekanalnom poslovnom okruženju postaju preokupacija maloprodavac i dobavljača.

Verovatnoća kupovine i ukupna vrednost kupca raste kada se informišu i odlučuju koristeći mobilne platforme (Ansar, Mela \& Neslin, 2008). Otuda i razvoj svojevrsnog višekanalnog menadžmenta kupaca i vezane strategije i taktike kupovnog marketinga, fokusiranih na veoma specifične i zahtevne aspekte privlačenja, zadržavanja i razvoja odnosa sa kupcima (Neslin, Grewal, Leghorn, Shankar, Teerling, Thomas \& Verhoef, 2006). Poslovni proces usmeren na višekanalne kupce (Neslin \& Shankar, 2009), koji su adekvatno strukturisani i selekcionisani (Kushwaha \& Shankar, 2007), postaje sui generis partnerska preokupacija maloprodavaca i dobavljača. Najteže je, pri tom, postići harmoničnost ponude $u$ različitim kanalima, uključujući cenu i ukupan osećaj kupca (Kushwaha \& Shankar, 2009).

Sa protokom vremena menja se i odnos važnosti uticaja na kupca van radnje i u njoj. Tradicionalna prodavnica za donošenje odluke o kupovini, prema nekim novijim istraživanjima, nije više važna kao nekada. Sve više kupaca odluku donosi van prodajnog objekta (Neff, 2009). Prema nekim istraživanjima, samo 30\% aktuelnih odluka o kupovini generiše se u prolazima i na prodajnim policama prodajnog objekta (Angrisani, 2015). Ovakvi nalazi upućuju na zaključak o plodnoj perspektivi istraživanja uticaja na kupca van tradicionalnih prodajnih objekata.

Sa kupovnim marketingom razvija se teorija maloprodajnog menadžmenta i marketinga, uključujući novu terminologiju. Polazište razvoja novih termina je, na primer, način dobijanja informacija $\mathrm{i}$ samog čina kupovine $\mathrm{u}$ uslovima višekanalnog informisanja i odlučivanja, što čini „hibridnu kupovinu” (Kalyanam \& Tsay, 2013). Otuda, pored ostalih, i termin boomerooming, za istraživačku aktivnost kupca na netu (Shankar \& Kushwaha, 2010), proveru saznanja u prodajnom objektu, a zatim i sam 
čin online kupovine (Boomerooming, 2015). Kupovina $\mathrm{u}$ fizičkoj prodavnici (Verhoef et al, 2007) prestaje da bude prioritet savremenog kupca.

Tradicionalna poslovna teorija i praksa gotovo isključivo tretira posetu kupca prodajnom objektu (Shankar et al, 2010). Savremeno poslovanje, bazirano na mobilnim tehnologijama i višekanalnim opcijama informisanja i izbora, podrazumeva zaokret u odnosu na tradicionalno viđenje maloprodaje. Poznati maloprodavci Macy's i Best Buy, na primer, nude aplikacije za uređaje iPhone i Android pomoću kojih detektuju i privlače kupce u blizini prodavnice. Servisi za društveno mapiranje i aplikacije Loopt i FourSquare Labs, takođe, imaju sličnu funkciju (Fowler, 2010).

Pored toga što unapređuju standarde kupovine, mobilni uređaji omogućavaju maloprodavcima da „posećuju“ okruženje kupaca, aktivno radeći na stimulisanju i unapređenju prodaje (Shankar et al, 2010). Partnerska saradnja maloprodavaca i dobavljača na kupovnom marketingu će se perspektivno razvijati $u$ pravcu proučavanja koncepcija ulaska maloprodavaca u okruženje kupaca, uključujući širinu i dubinu izazova razvoja adekvatnih pristupa za različite prepoznate situacije (Fowler, 2010). Nesumljivo je da je perspektivna i veoma važna tema postizanja balansa međusobnih poseta kupaca i maloprodavaca, sa adekvatnim metrikama dobrih rezultata za obe strane.

Za maloprodavce i dobavljače je perspektivno osetljiva tema definisanja procesa kupovine (Hoyt, 2006) u višekanalnom okruženju, uključujući momente transformacije potrošača $u$ kupca i obratno, sa akcentima tradicionalne i savremene poslovne prakse. Razvoj novog pogleda na okidače kupovine u brick and click situacijama kupovine, sa težištem na održivoj odmerenosti i sinhronizaciji stimulanasa i uticaja, podrazumevaće novi konsenzus oko uvida o kupcima, na nivou konkretnog brenda i kupovnih situacija.

Budućnost partnerstva na kupovnom marketingu će svakako biti određena i novim razumevanjem interesa $\mathrm{i}$ redefinisanjem poslovnih procesa $\mathrm{u}$ skladu sa konsenzusom i zahtevima novih rešenja. Perspektiva realizacije zadatka da sve tri strane budu na dobitku (kupac, maloprodavac i dobavljač) će dodatno postati izazovna sa redefinisanjem pozicija i uloga $u$ kanalima marketinga, i novim ambicijama učesnika u kupovnom marketingu. Novi momenti ponašanja maloprodajnih organizacija u okruženju kupaca će predstavljati nove mogućnosti i izazove za dobavljače koji rade na razvoju inovativnog pristupa brend menadžmentu.

Pre razvoja novih aspekata višekanalnog kupovnog marketinga pred maloprodajnim i dobavljačkim partnerima stoji zahtev jasnog pozicioniranja kupovnog marketinga $u$ tradicionalno viđenim organizacijama. Neophodno je $\mathrm{u}$ aktuelnom trenutku razgraničiti odgovornosti za kupovni marketing $\mathrm{u}$ odnosu na tradicionalna organizaciona rešenja, kako bi zahtevana organizaciona struktura bila efikasna i efektivna. Polazište novih struktura su svakako nedostajući razvijeni standardi prakse kupovnog marketinga, sa razgraničenim odgovornostima i opisima radnih mesta, za koja postoje definisana znanja i veštine. Da bi praksa kupovnog marketinga mogla da napreduje u pravcu korišćenja potencijala mobilnih platformi i višekanalnog poslovanja neohodno je partnerski razjasniti i rešiti navedena i druga bazična pitanja od suštinskog značaja za efikasnost i efektivnost unapređenog tretmana kupaca (Hoyt \& Swift, 2014).

\section{ZAKLJUČAK}

Realizovano istraživanje partnerske perspektive kupovnog marketinga, pored toga što dodatno osvetljava strategijsku važnost pažljivog tretmana i satisfakcije kupca od strane maloprodavca i dobavljača, upućuje na ključne aspekte harmonizacije odnosa u kanalima marketinga na planu kupovnog marketinga. Istraživanje ukazuje na elemente efikasne ponude i efikasne usluge kupca, akcentujući neophodnost sistematične partnerske brige o kupcu u svim koracima procesa kupovine. S obzirom na važnost, istraživanjem je izdvojena prilagođenost i raspoloživost ponude, kao i krucijalni značaj profilisane i balansirane aktivnosti unapređenja ponude.

Doprinos realizovanog istraživanja je i jasno identifikovanje temeljnog problema implementacije kupovnog marketinga sadržanog $\mathrm{u}$ izazovu promene poslovnog fokusa sa potrošača na kupca, uključujući 
pitanja poslovne kulture, profilisanja strategije, novih poslovnih procesa, pozicija i odgovornosti. Izazovi $\mathrm{su}, \mathrm{s}$ jedne strane, internog tipa, dok, s druge strane, dobijaju interorganizacijski karakter, naročito kada je u pitanju harmonizacija partnerskog delovanja i efektivnost kupovnog marketinga.

Polazeći od redefinisanja poslovne pažnje u pravcu razumevanja i satisfakcije kupca, rad trasira novu logiku menadžmenta kategorije proizvoda, tradicionalno usmerenog na potrošača $u$ prodajnom objektu. S tim u vezi, sugerišu se dva ključna inovativna momenta u strategiji i taktici menadžmenta kategorije proizvoda. Kao prvo, kupac i temeljni uvidi o kupcima su novo polazište menadžmenta kategorije. Kao drugo, trasirana je podela poslovnog procesa na dva dela, i to na strategijski i operativni deo. Strategijski deo, definisanje kategorije i njene uloge, nije predmet kontinuiranog razmatranja i redefinisanja. Na drugoj strani, sugeriše se intenzivna operativna aktivnost menadžmenta kategorije na nivou uvida o kupcima, poslovnog planiranja, realizacije planova, supervizije i razvoja poslovnog procesa. Time je postignuta ušteda vremena i drugih resursa, a napor menadžmenta kategorije je efikasno usredsređen na unapređenje iskustva kupovine vezanog za prodavnicu, kategoriju $\mathrm{i}$ brend.

Trasiranjem efikasnijeg, ka kupcu orijentisanog menadžmenta kategorije kao krovnog poslovnog koncepta, formirano je polazište razvoja adekvatne metrike poslovnih rezultata kupovnog marketinga. $\mathrm{U}$ radu se razjašnjava širenje i produbljivanje horizonta merenja poslovnih rezultata, polazeći od višefunkcionalnog i višeprocesnog karaktera kupovnog marketinga. S tim u vezi, realizovanim istraživanjem se definiše Model partnerskog stvaranja vrednosti u kanalima marketinga. U pitanju je dinamičan pogled na listu rezultata, na nivou transakcija i ponašanja kupaca, primereno progresu kupovnog marketinga.

Navedenim rezultatima istraživanja je nedvosmisleno potvrđena polazna hipoteza da se efektivan i efikasan kupovni marketing zasniva na balansiranom partnerstvu maloprodavaca i dobavljača, a koje je podržano unapređenim menadžmentom kategorije proizvoda i prilagođenom metrikom perfromansi. U prilog datoj tvrdnji stoje i zaključci o institucionalizaciji saradnje na kupovnom marketingu, što predstavlja novu, nedovoljno proučenu paradigmu konkurencije i saradnje u kanalima marketinga.

Aspekt profilisanog partnerstva na kupovnom marketingu posebno dolazi do izražaja u uslovima višekanalnog poslovanja, kada je posebno izazovno postići harmoničnost ponude. Hibridne kupovine, na mobilnim platformama i promenljivost uticaja i ponašanja kupaca, predstavljaju aktuelno i perspektivno polje istraživanja saradnje maloprodavaca i dobavljača.

Otvoreno naučno i praktično pitanje kupovnog marketinga, pored ostalog, predstavlja standardizacija pristupa kupovnog marketinga, sa nejasnim razgraničenjima odgovornosti. Teorija i praksa nije dovoljno razjasnila efikasan put prihvatanja i implementacije strategije i taktike kupovnog marketinga, sa jasnim internim i interorganizacijskim razgraničenjima pozicija, znanja i veština. Timski rad $\mathrm{u}$ uslovima koegzistencije tradicionalne orijentacije na potrošača i novog akcentovanja vrednosti kupca takođe predstavlja perspektivno polje istraživanja implementacije kupovnog marketinga.

Koncepcija kupovnog marketinga je nesumljivo atraktivna i u domaćim poslovnim uslovima koje karakteriše internacionalizacija $\mathrm{i}$ koncentracija $\mathrm{u}$ kanalima marketinga, kao i ograničenje nedostatka validne evidencije poslovne prakse. S jedne strane, uočljivi su programi kupovnog marketinga afirmisani od strane pojedinih prisutnih multinacionalnih kompanija. S druge strane, nejasno je da li domaće kompanije praktikuju kupovni marketing. Štaviše, osnovan je skepticizam primene novog marketinga, $\mathrm{u}$ uslovima problematične primene i tradicionalnog marketinga. Ipak, za očekivati je da će nedvosmislenost pozitivnih efekata kupovnog marketinga i uspešna praksa vodećih internationacionalnih kompanija koje posluju na domaćem tržištu neminovno voditi širenju i unapređenju prakse kupovnog marketinga i u domaćim kompanijama kako maloprodavaca, tako i dobavljača, a na opštu dobrobit i jednih i drugih i, pre svega, kupaca. 


\section{REFERENCE}

Angrisani, C. (2015). Study: Shopper marketing spending doubles. Retrieved October 26, 2015, http://supermarketnews. com/marketing/study-shopper-marketing-spendingdoubles\#ixzz3VEeI9Shq

Ansari, A., Mela, C. \& Neslin, S. (2008). Customer Channel Migration. Journal of Marketing Research, 45(1), 60-76. doi: 10.1509/jmkr.45.1.60

Bhasin, K. (2012). Macy's Quietly Recognizes That JCPenney CEO Ron Johnson Might Be On To Something. Retrieved October 29, 2015, http://www.businessinsider.com/jcpenney-ronjohnson-shop-in-shop-2012-9

Bogetić, Z. (2007). Menadžment kategorije proizvoda. Beograd, Republika Srbija: Data Status, CID Ekonomskog fakulteta Univerziteta u Beogradu.

Bogetić, Z. i Petković, G. (2014). Kako pripremiti trgovinsko poduzeće za shopper marketing? U N. Knego, S. Renko, i B. Knežević (Ur.). Perspektive trgovine 2014: Ljudi, tehnologija, znanje (str. 140-154). Zagreb, Hrvatska: Ekonomski fakultet Univerziteta u Zagrebu.

Boomerooming - Bad News for Bricks and Mortar Retailers (2014). Retrieved October 11, 2015, https://www.redsnapper. net/boomerooming

Buckler, S. A., \& Zien, K. A. (1997). The Spirituality of Innovation: Learning from Stories. Engineering Management Review, 25(4), 89-102.

Egol, M., Sarma, R., \& Sayani, N. (2013). Reimagining shopper marketing: Building brands through omnichannel experiences. Strategy \& pwc, 10. Retrieved October 19, 2015, http://www.strategyand.pwc.com/global/home/what-wethink/reports-white-papers/article-display/reimaginingshopper-marketing

Fam, K. S., Merrilees, B., Richard, E. J., Joysa, L., Li, Y., \& Krisjanous, J. (2011). In-store marketing: a strategic perspective. Asia Pacific Journal of Marketing and Logistics, 23(2), 165-176. doi:10.1108/1555851111120470

FMI, (2015). U.S. Grocery Shopper Trends 2015- Executive Summary. Retrieved November 10, 2015, http://www.fmi. org/docs/default-source/document-share/fmitrends15-execsumm-06-02-15.pdf?sfvrsn=2

Fowler, G. A., (2010). Retailers Reach Out on Cellphones: Software Apps Lure Shoppers with Rewards, Coupons and Product Information. The Wall Street Journal, 21, B6.

Fowler, D., \& Goh, B. (2012). Retail Category Management. New Jersey, Columbus: Pearson Education.
Gilbride, T. J., Inman, J. J., \& Stilley, K. M. (2013). What Determines Unplanned Purchases?: A Model Including Shopper Purchase History and Within-Trip Dynamics. Wharton School - University of Pennsylvania. Retrieved October 18, 2015, https://marketing.wharton.upenn.edu/mktg/ assets/File/Dynamic\%20Effects\%20in\%20Unplanned\%20 Purchase\%20Behavior\%202-18-13.pdf

GMA \& Deloitte, (2008). Delivering the Promisse of Shopper Marketing: Mastering Execution for Competitive Advantage. Retrieved November 10, 2015, https://www.gmaonline. org/downloads/research-and-reports/GMA-Deloitte_ ShopperMktReport_FINAL.pdf

Goldberger, N. (1990). Notes on qualitative research. The Fielding Institute, Santa Barbara, CA.

Guglielmi, K. A. (2000). Crisis Induceced Learning in a Small Business: A Case Study. Unpublished doctoral dissertation, University of Connecticut, Storrs, Connecticut, United States.

Hoyt, C. (2006). Shopping for Consumers. Retrieved November 27, 2015, http://hubmagazine.com/archives/the_hub/2006/ may_jun/the_hub12_hoyt.pdf

Hoyt, C., \& Swift, N. (2014). Up, Up \& Away. The Hub, July/ August, 42-45. Retrieved November 10, 2015, http:// hubmagazine.com/archives/the_hub/2014/jul_aug/the_ hub61_hoyt.pdf

IELKA, (2013). Productivity and Efficinecy in Grocery Retail. Retrieved November 11, 2015, www.ielka.gr

Inman, J. J., Winer, R. S., \& Ferraro, R. (2009). The Interplay Among Category Characteristics, Customer Characteristics, and Customer Activities on In-Store Decision Making. Journal of Marketing, 73(5), 19-29. doi: http://dx.doi.org/10.1509/ jmkg.73.5.19

Interbrand - The science of shopper insights (2015). Retrieved October 9, 2015, http://www.interbranddesignforum.com/ wordpress/category/shopper-sciences/

Kalyanam, K., \& Tsay, A. A. (2013). Free riding and conflict in hybrid shopping environments: Implications for retailers, manufacturers, and regulators. The Antitrust Bulletin, 58(1), 19-68.

Kapferer, J. N. (2008). The New Strategic Brand Management. London, UK: Kogan Page.

Khuller, M. (2013). Shopper Marketing's ROI. ADMAP.

KiE Square Perspective. Analytic driven competitive edge in shopper marketing. Retrieved November 20, 2015, http:/ www.kiesquare.com/shoptalk/pdf/KiE\%20Square\%20 Perspective_Analytics\%20Driven $\% 20$ Competitive $\% 20$ 
Edge\%20in\%20Shopper\%20Marketing.pdf

Kushwaha, T. L., \& Shankar, V. (2007). Optimal Allocation of Marketing Efforts by Customer-Channel Segment. Marketing Science Institute, 07-207. Cambridge, Massachusetts.

Kushwaha, T. L., \& Shankar, V., (2009). Are Multichannel Customers Always the Most Valuable Customers? An Empirically Generalizable Multicategory Analysis. Working Paper. North Carolina: University of North Carollina, Chapel Hill.

Marinkovic, V., \& Senic, V. (2012). Analysis of service quality elements in corporate banking. Economic Horizons, 14(1), 1524. doi:10.5937/ekonhor1201013M

Marshal, C., \& Rossman G. B. (1995) Designing Qualitative Research. Sage Publications, Thousand Oaks.

Mesihović, N. (2003). Uvod u metodologiju društvenih nauka. Sarajevo, Bosna i Hercegovina: Ekonomski fakultet.

Mucchielli, A. (1996). Dictionnaire des methodes qualitatives en sciences humaine et sociales. Paris, Francia: Armand Colin.

Neff, J. (2009). Trouble in Store for Shopper marketing? Advertising Age, 80(8), 3-32.

Neslin, S. A., Grewal, D., Leghorn, R., Shankar, V., Teerling, M. L., Thomas, S. J., \& Verhoef, C.P. (2006). Challenges in Multichannel management. Journal of Service Research, 9(2), 95-113.

Neslin, S. A., \& Shankar, V. (2009). Key Issues in Multichannel management: Current Knowledge and Future Directions. Journal of Interactive Marketing, 23(1), 70-81. doi:10.1016/j. intmar.2008.10.005

O'Leary, N. (2013). Shopper Marketing Is Going MainstreamRetail is the center of gravity. Adweek. Retrieved November 5 , 2015, http://www.adweek.com/news/advertising-branding/ shopper-marketing-going-mainstream-149630

Petković, G., \& Bogetić, Z. (2014). Different perspectives of the retail marketing development. In N. Janićijević (Ed.). Contemporary Management and Marketing Methods in Improving Competitiveness of Companies in Serbia in the Process of its Integration in European Union (pp. 105-118). Belgrade, Republic of Serbia: CID of The Faculty of Economics University of Belgrade.

Pincott, G. (2012). Point of view on shopper marketing. In M. Stahlberg, \& V. Maila, (Eds.). Shopper Marketing: How to Increase Purchase Decisions at the Point of Sale, 2nd ed. (pp. 9-12). London, UK: Kogan Page.

Revolutionary In-Store Insights: Endcap Displays and the Shopper, from the Category Management Association, (white paper). How Are Shoppers Reacting to Endcap Displays?
Retrieved October 25, 2015, http://www.shoppertech.org/ CM021315.html. Retrieved October 28, 2015, from http:// www.videomining.com/

Shankar, V. (2011). Shopper Marketing. Cambrige, Massachusetts: Marketing Science Institute.

Shankar, V., \& Bolton, R. (2004). An Empirical Analysis of Determinants of Retailer Pricing Strategy. Marketing Science, 23(1), 28-49. doi: 10.1287/mksc.1030.0034

Shankar, V., \& Balasubramanian, S. (2009). Mobile Marketing: A Synthesis and Prognosis. Journal of Interactive Marketing, 23(2), 118-129. doi: 10.1016/j.intmar.2009.02.002

Shankar, V., Alladi, V., Hofacker, C., \& Naik, P. (2010). Mobile Marketing in the Retailing Environment: Current Insights and Future Research Avenues. Journal of Interactive marketing, 20(2), 111-120. doi: 10.1016/j.intmar.2010.02.006

Shankar, V., \& Kushwaha, T. L. (2010). An Empirical Analysis of Cross-Channel Effects in a Multichannel Environment. Working Paper, College Station: Texas A\&M University.

Shankar, V., Inman, J. J., Mantala, M., Kelley, E., \& Rizley, R. (2011). Innovations in Shopper Marketing: Current Insights and Future Research Issues. Journal of Retailing, 87 (Supplement 1), 29-42. doi:10.1016/retai.2011.04.007

Shopper Marketing Best Practices: A Collaborative Model for Retailers and Manufacturers. A Report from Retail Commission on Shopper marketing (2010). Retrieved October 29, 2015, http://ecr-all.org/files/RetailCommission_executivereport-2010.pdf.

Shopping Marketing Best Practices. (2010).

Silveira, P., \& Marreiros, K. (2014). Shopper Marketing: A Literature Review. International Review of Management and Marketing, 4(1), 90-97.

Sorensen, H. (2009). The in-store audience. Journal of Advertising Research, 49(2), 176-179. doi:10.2501/S0021849909090242

Stahlberg, M., \& Ville, M. (2012). Shopper Marketing. 2nd Edition. London, UK: Kogan Page.

Stojanovic, Z., Filipovic, J., \& Stojkovic, D. (2014). Markets of Food with Nutritive and Health Claim: Producers and Retailers Perspectives. Economic Horizons, 16(1), 63-75. doi:10.5937/ekonhor1401063S

Verhoef, P. A., Neslin, S. A., \& Vroomen, B. (2007). Multichannel customer management: Understanding the researchshopper phenomenon. International Journal of Research in Marketing, 24(2),129-148. doi: 10.1016/j.ijresmar.2006.11.002.

Wyner, G. (2011). Shopper Marketing. Journal of Marketing Management, 20(1), 44-47. 
Zoran Bogetić je vanredni profesor na Ekonomskom fakultetu Univerziteta u Beogradu, na kome učestvuje $u$ izvođenju nastave na predmetima: Kanali marketinga, Trgovinski menadžment, Trgovinski marketing i menadžment prodaje i Menadžment lanca snabdevanja. Aktuelna istraživačka i konsultantska preokupacija uključuje oblasti: menadžment kanala marketinga, menadžment kategorije proizvoda, menadžment lanca snabdevanja, strategije efiksanog odgovora potrošaču, menadžment odnosa sa kupcima i kupovni marketing.

Đorđe Kaličanin je vanredni profesor na Ekonomskom fakultetu Univerziteta u Beogradu, na kojem je diplomirao, magistrirao i doktorirao. Na osnovnim akademskim studijama predaje Strategijski menadžment, a na master akademskim studijama Menadžersko odlučivanje, Strategijske finansije i Poslovnu strategiju. Njegov poseban istraživački interes su menadžment vrednosti preduzeća, tehnike strategijskog planiranja i strategijske implementacije, sistemi merila performansi.

Dragan Stojković je docent na Ekonomskom fakultetu Univerziteta u Beogradu. Učestvuje u izvođenju nastave na nastavnim predmetima: Kanali marketinga, Trgovinski marketing i menadžment prodaje, Trgovinski menadžment, Strategije kanala marketinga i Elektronska trgovina i e-biznis. Njegov naučnoistraživački fokus uključuje: višekanalnu strategiju, maloprodajni marketing i menadžment, elektronsku trgovinu i Internet marketing. 


\title{
SHOPPER MARKETING: A NEW PARTNERSHIP PERSPECTIVE IN MARKETING CHANNELS
}

\author{
Zoran Bogetic, Djordje Kalicanin and Dragan Stojkovic
}

Faculty of Economics, University of Belgrade, Belgrade, The Republic of Serbia

\begin{abstract}
Shopper marketing has lately become a promising business initiative. The distinction between shopper marketing and traditional marketing paves the way for new relations, partnerships, and better results of retailers and suppliers. The paper explains the new perspective of marketing, with the shopper in focus. Retail has been identified as the center of gravity for enterprise cooperation and a new business consensus. The advantages and challenges of shopper marketing are also explained, including tracing the efficient category management model and partnership value creation. In the wake of the development of new category management guidelines, the paper points out the aspect of the institutionalization of cooperation in shopper marketing, as well as the future of multi-channel analysis and customer satisfaction.
\end{abstract}

Keywords: shopper marketing, shopper insights, partnership, category management

JEL Classification: M21, M31, L25, L81 